Discussion Paper No. 16-064

\title{
Does State Aid for Broadband Deployment in Rural Areas Close the Digital and Economic Divide?
}

Wolfgang Briglauer, Niklas S. Dürr, Oliver Falck, and Kai Hüschelrath

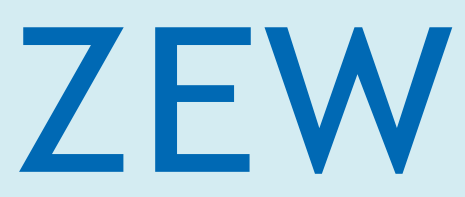

Zentrum für Europäische Wirtschaftsforschung $\mathrm{GmbH}$

Centre for European

Economic Research 
Discussion Paper No. 16-064

\title{
Does State Aid for Broadband Deployment in Rural Areas Close the Digital and Economic Divide?
}

\author{
Wolfgang Briglauer, Niklas S. Dürr, Oliver Falck, \\ and Kai Hüschelrath
}

Download this ZEW Discussion Paper from our ftp server:

http://ftp.zew.de/pub/zew-docs/dp/dp16064.pdf

Die Discussion Papers dienen einer möglichst schnellen Verbreitung von neueren Forschungsarbeiten des ZEW. Die Beiträge liegen in alleiniger Verantwortung der Autoren und stellen nicht notwendigerweise die Meinung des ZEW dar.

Discussion Papers are intended to make results of ZEW research promptly available to other economists in order to encourage discussion and suggestions for revisions. The authors are solely responsible for the contents which do not necessarily represent the opinion of the ZEW. 


\title{
DOES STATE AID FOR BROADBAND DEPLOYMENT IN RURAL AREAS CLOSE THE DIGITAL AND ECONOMIC DIVIDE?
}

\author{
Wolfgang Briglauer*, Niklas S. Dürr ${ }^{\dagger}$, Oliver Falck ${ }^{\circ}$ and Kai Hüschelrath*
}

October 2016

\begin{abstract}
We evaluate the impact of a major European state aid program for broadband deployment applied to rural areas in the German State of Bavaria in the years 2010 and 2011. Using difference-in-differences estimation strategies, we find that aided municipalities have depending on broadband quality - a between 16.8 and 23.2 percent higher broadband coverage than non-aided municipalities. This increase in broadband coverage - closing the digital divide - results in an increase of on average seven employed individuals living in the respective aid-receiving municipalities while leaving the number of employed or selfemployed individuals or wages unaffected. We therefore conclude that an increase in broadband coverage through state aid prevents rural areas from depopulation, but does not contribute to a further closing of the economic divide in the form of creating new jobs.
\end{abstract}

JEL Class: D62; D73; G38; H23; J23; K23; L52; L96; L98; R23

Keywords: Government policy; state aid; ex-post evaluation; broadband; employment, rural areas; European Union; Germany; Bavaria

* ZEW Centre for European Economic Research, MaCCI Mannheim Centre for Competition and Innovation, P.O. Box 1034 43, D-68034 Mannheim, Germany, E-mail: briglauer@zew.de. We are grateful to Sven Heim and Nicolas van Zeebroeck as well as participants at the $14^{\text {th }}$ ZEW Conference on the Economics of ICT in Mannheim in June 2016 and the $43^{\text {rd }}$ Annual EARIE Conference in Lisbon in August 2016 for valuable comments on earlier versions of the article and to Benedikt Kauf for excellent research assistance. We thank axciom for providing us with detailed data on the number of freelancers.

$\dagger$ ZEW Centre for European Economic Research, MaCCI Mannheim Centre for Competition and Innovation, P.O. Box 1034 43, D-68034 Mannheim, Germany, E-mail: duerr@zew.de.

University of Munich and Ifo Institute - Leibniz Institute for Economic Research at the University of Munich, and CESifo, Poschingerstraße 5, D-81679 Munich, Germany, E-mail: falck@ifo.de. Corresponding author.

* University of Mannheim and ZEW Centre for European Economic Research and MaCCI Mannheim Centre for Competition and Innovation, P.O. Box 1034 43, D-68034 Mannheim, Germany, E-mail: hueschelrath@zew.de. 


\section{Introduction}

The study of the interrelationship between various types of infrastructure investments and economic development has fascinated generations of researchers. While there appears to be little dispute on the positive impact of the general provision of infrastructures such as transportation or communication networks on employment, innovation and growth, the question of the socially optimal degree of network deployment in general and the most suitable financing options in particular are much more controversial.

While historically the (seemingly) public good character of many infrastructures suggested their entirely public provision, the liberalization processes in many network industries in the 1980 s and 1990s broadened the financing options to entirely private or public-private investment projects. The public provision of infrastructures is more and more seen as limited to cases of market imperfections, i.e., situations in which market forces alone are unlikely to provide the socially optimal level of network deployment. ${ }^{1}$

In the European Union, the belief in the strategic importance of broadband infrastructures for economic development has long been affecting policy making - most recently reflected prominently in the European Commission's Digital Agenda for Europe. ${ }^{2}$ In working towards the envisaged goals - nationwide coverage of broadband above $30 \mathrm{Mbit} / \mathrm{sec}$ and 50 percent of the households in the EU to be subscribed to broadband above $100 \mathrm{Mbit} / \mathrm{sec}$ by 2020 - the European Commission first and foremost aims at strengthening the incentives of private companies to invest in both the deployment of broadband infrastructures and subscriptions through the design and implementation of appropriate regulatory frameworks.

Since 2003, this general strategy includes the granting of state aid in cases of particular rural areas where the private investment incentives are considered insufficient due to the interference of large deployment costs and limited revenue potentials. In fact, between 2003 and 2014, the European Commission has approved in sum 136 state aid applications ${ }^{3}$ of mostly regions - but also entire (smaller) countries - in the European Union for the deployment of broadband networks in rural areas aiming at closing the digital divide and triggering welfare enhancing externalities that are expected from a well-established broadband infrastructure as 'general purpose technology' (see Bresnahan and Trajtenberg, 1995).

Aiming at evaluating the impact of such state aid programs for broadband deployment in rural areas, two consecutive general research questions suggest themselves: First, from an effectivity perspective, had the granting of state aid the desired direct effect; i.e., in the case of

1 It should be noted here that the identification of the socially optimal level of network deployment is a complex and therefore error-prone process. For example, it cannot be ruled out that a state authority decides to provide funding for an extension of a certain infrastructure to rural areas and later learns that only a small fraction of the respective individuals are interested in using (and paying for) the respective infrastructure (thus suggesting an inefficient investment decision).

2 See https://ec.europa.eu/digital-agenda/en (last accessed on 1 July 2016) for further information.

3 See http://ec.europa.eu/competition/sectors/telecommunications/broadband_decisions.pdf (last accessed on 1 July 2016) for a full list of Commission decisions on State aid to broadband. 
broadband aid, did the granting of financial aid to firms lead to an improved broadband coverage in the respective regions or municipalities (and to what degree)? Second, from an efficiency perspective, the broader question is raised whether the respective state aid scheme is socially desirable? In the case of broadband aid, such a broader assessment of social costs and benefits has to go beyond the direct effects of the aid and additionally has to take various (positive or negative) indirect effects of the granting of aid on, e.g., competition, trade, employment, investment or economic growth into account. ${ }^{4}$

We are the first to assess the causal effects of one of such state-aid policies on a fine geographic scale. Particularly, we are interested in the effects of the state aid program for broadband deployment in the German State of Bavaria in the years 2010 and 2011 on broadband coverage (first stage effectivity question) and employment (second stage efficiency question). We concentrate on employment as second-stage outcome variable as it is, first, of key interest for public policy makers and, second, likely to react rather quickly to policy changes such as the granting of state aid and the deployment of broadband infrastructure. Applying a difference-in-differences (DiD) estimation strategy on the basis of a matched sample of 1,845 aided and non-aided rural municipalities, we find with respect to the effectivity question that the aided municipalities have - depending on broadband quality - a between 16.8 and 23.2 percent higher broadband coverage than non-aided municipalities. Concerning answers to the subsequent efficiency question, we combine our DiD strategy with an instrumental variables (IV) strategy in order to estimate the effect of the state aid-induced increase in broadband coverage on employment. We find a significant and positive effect of the state aid program on employed individuals living in the respective aid-receiving municipalities; however, neither the number of employed measured at place of work or selfemployed individuals nor the average wages show any significant effect. We therefore conclude that an increase in broadband coverage attracts workers to live in these rural municipalities - or prevents them from depopulation, respectively - however, without attracting additional economic activity necessary to close the economic divide.

The remainder of the article is organized as follows. The second section presents a brief review of the existing literature on the economic impacts of telecommunications networks and broadband internet. It also contains a review of the literature on the impact of alternative public policies on broadband deployment. The third section continues with a description of the institutional structure of broadband state aid in the European Union in general and its implementation in the German State of Bavaria in particular. The fourth section provides a detailed characterization of our empirical strategy. The fifth section describes our data, followed by the presentation and discussion of our estimation results in section six. Section seven concludes the paper with a review of its main results and the identification of avenues for future research.

4 Ideally, such an analysis will also have to consider a possible 'beggar-thy-neighbor problem' suggesting negative effects on total welfare. 


\section{Review of related literature}

The study of the economic impacts of telecommunications networks and broadband internet together with the impact of alternative public policies on broadband deployment - has attracted a significant amount of research. For example, a recent survey by Bertschek et al. (2016) reviews more than 60 studies that econometrically investigate the effects of communication networks on economic growth, employment, regional development as well as productivity and firm/market performance. In the remainder of this section, we limit our review of the literature to, first, studies that quantitatively assess the impact of state aid (subsidies) on broadband deployment (Section 2.1) and, second, contributions related to the impact of broadband availability (or adoption) on employment as key outcome variable (Section 2.2).

\subsection{The impact of state aid on broadband deployment}

The impact of state aid on broadband deployment - i.e., the effectivity question - is only investigated by a few studies all making use of highly aggregated country-level data. Furthermore, the studies typically do not go beyond simple multivariate regressions. In an early contribution, Belloc et al. (2012) examine the impact of public policies on broadband adoption by utilizing a data set for 30 OECD countries that contains public funding measures, as well as the countries' socio-economic and demographic conditions for the years from 1995 to 2010. The authors find a positive and significant effect of demand-side policies - which is higher when the broadband adoption is already developed - while the effect of supply-side policies decreases as the broadband market moves into its later stages.

Paleologos and Polemis (2013) also utilize data for 30 OECD countries for the years from 1988 to 2010 in order to examine the impact of the regulatory environment on telecommunications investments and economic growth controlling for the industry structure and competition in the market. They find that the regulatory variable - as measured by the OECD Regulatory Reform Index - has a significantly positive effect on both the level of investments and economic growth in both the static and the dynamic model specifications.

Montolio and Trillas (2013) measure how the level of broadband adoption is affected by the impact of regulation, the degree of centralization of regulatory decisions as well as industrial policy. The authors employ an industrial policy variable that stands as a proxy for public policies devoted to foster broadband penetration and is calculated as government subsidies to private and public companies as percentage of GDP. The authors utilize data sets for OECD and EU countries for the years from 1999 to 2006 and find positive, albeit insignificant, effects of subsidies in all model specifications.

\subsection{The impact of broadband deployment on economic outcomes}

Since we are primarily interested in employment effects, we concentrate the review on such contributions. ${ }^{5}$ Applying US county- or ZIP code-level data, Kandilov and Renkow (2009) and partly also Kolko (2012) find positive links between broadband (availability or adoption) and employment growth. Using a large Canadian data set on the municipality-level from 1997

5 For a comprehensive review on various economic outcomes, see Bertschek et al. (2016). 
to 2011, Ivus and Boland (2016) find a similar significantly positive impact of broadband availability on employment growth in rural areas as well as overall wage growth (particularly created by the service sector). Furthermore, as shown by Atasoy (2013) for county-level US data, taking into account differences in urbanization and workers' skill levels suggest that the effect of broadband is significant mostly in rural areas and for high-skilled workers. The stronger impact on remote areas lends support to the notion that broadband can help these regions to catch up with more economically developed urban areas. Last but not least, Fabritz (2013) investigates the impact of broadband on economic activity in rural areas of Germany. Using panel data on broadband coverage in 8,460 West German municipalities from 2005 to 2009, she finds a positive but limited relationship between local employment and local broadband infrastructure (with the effect being larger in rural municipalities). A 10 percentage point increase in broadband availability in rural areas is associated with a 0.09 to 0.15 percentage points increase in the local employment rate.

In addition to the effects on employment types and levels - investigated further in our empirical analysis below using micro-data on the municipality level for rural areas of Bavaria - recent quantitative studies also investigate a possible impact of broadband availability (or adoption) on wages and labor productivity of particularly high-skilled workers. In particular, for the US, Forman et al. (2012) find that diffusion of advanced Internet comes along with significant wage and employment growth only for locations with high IT use, high income and population density. Akerman et al. (2015) analyze the impact of broadband on labor productivity with Norwegian firm and worker data from 2000 to 2008 taking the workers' skill levels into account. They find that broadband availability improves the labor market outcomes and marginal productivities of highly skilled/educated workers but has a detrimental effect on unskilled/uneducated workers. Since jobs for more skilled workers are typically better paid, broadband might therefore increase the wage gap.

In sum, our review of the existing literature suggests that employment effects of broadband deployment are often found empirically - however, they tend to be rather small in size and often show some heterogeneity with respect to urban and rural areas on the one hand and lowand high-skilled workers on the other.

\section{Institutional background on broadband state aid}

In this section, we present important institutional background on the granting of broadband state aid. While Section 3.1 briefly describes the broadband state aid rules in the European Union $^{6}$, Section 3.2 continues with a detailed characterization of the broadband state aid programs in Bavaria.

\subsection{Broadband state aid in the European Union}

According to Article 107 of the Treaty on the Functioning of the European Union (TFEU), state aid is defined as “... any aid granted by a Member State or through State resources in

\footnotetext{
As one out of 16 states that constitute the Federal Republic of Germany, European laws and regulations apply to the State of Bavaria.
} 
any form whatsoever which distorts or threatens to distort competition by favoring certain undertakings or the production of certain goods ...". Granting state aid is generally prohibited unless it is justified by reasons of general economic development. To ensure that this prohibition is respected and exemptions are applied equally across the European Union, the European Commission is in charge of ensuring that state aid complies with EU rules.

For the case of telecommunications and broadband infrastructures, the European Union has long recognized their strategic importance in promoting the key objectives of creating common European markets in general and fostering economic development in the Member States in particular. Most recently, in its Digital Agenda for Europe, the Commission therefore envisages concrete goals in the form of the nationwide coverage of broadband above $30 \mathrm{Mbit} / \mathrm{sec}$ and 50 percent of the households in the EU to be subscribed to broadband above $100 \mathrm{Mbit} / \mathrm{sec}$ by the year 2020. Although the Commission first and foremost aims at strengthening the incentives of private companies to invest in both the deployment of broadband infrastructures and subscriptions through the design and implementation of appropriate regulatory frameworks, since 2003, it explicitly allows the granting of state aid in cases of particular rural areas where the private investment incentives are considered insufficient due to the interference of large deployment costs and limited revenue potentials.

In order to reach its self-imposed goal of "well-designed aid targeted at market failures in order to achieve growth-enhancing priorities' (European Commission, 2012) - the Commission has adopted detailed broadband state aid rules which specify the conditions on how public funding could be provided for broadband deployment. According to the guidelines - originally adopted in $2009^{7}$ and revised in $2013^{8}$ - the Commission supports public funding for broadband network deployment in rural and underserved 'white' areas where no broadband infrastructure exists or where no plans by private investors to roll out such an infrastructure exist in the near future. In providing funds, member states should pursue genuine cohesion and economic development as main objectives (\$40-42). In so-called 'grey' areas where only one broadband network operator is present, a more detailed assessment is required for state aid approval as market distortions become more likely in those areas ( $\$ 44-$ 46). Finally, there is, in principle, no role for state aid in competitive 'black' areas with two or more existing broadband infrastructures ( $\$ 43)$.

\subsection{Broadband state aid programs in Bavaria}

In the year 2007, the German State of Bavaria ${ }^{9}$ - consisting of 2,056 distinct municipalities started the initiative 'Broadband for Bavaria' aiming at informing local municipalities on general possibilities to foster the deployment of broadband networks in rural areas. The

7 European Commission (2009), Community rules for the application of state aid rules in relation to rapid deployment of broadband networks, Official Journal of the European Union 2009/C 235.

8 European Commission (2013), EU Guidelines for the application of state aid rules in relation to the rapid deployment of broadband networks, Official Journal of the European Union 2013/C 25.

9 In 2015, Bavaria generated a (nominal) GDP of about $€ 550$ billion making it the second largest German state after North Rhine-Westphalia (with a GDP of about $€ 646$ billion). Although part of the Federal Republic of Germany, Bavaria therefore had a larger GDP than entire EU member states such as Austria (about $€ 337$ billion in 2015), Belgium (about $€ 529$ billion in 2014) or Poland (about $€ 545$ billion in 2014). Data sources: Statistical Offices of the Federation and the Länder and World Bank. 
initiative was motivated by a slower broadband deployment in Bavaria - compared to other German states - for reasons such as a lower population density, a high share of rural areas with numerous far-flung municipalities, and difficult topographical conditions with mediumand high-range mountains. Moreover, the divergence in broadband coverage between rural and urban regions was substantial.

Guided by the aim of providing equivalent working and living conditions in the entire state, in November 2007, the Bavarian government decided to support the deployment of broadband in rural areas from the year 2008 onwards (see generally Bavarian Ministry of Economic Affairs and Media, Energy and Technology, 2012).

Following this initiative by one federal state, the German Federal Government notified the European Commission about its intended policy to support rural areas all over Germany in the deployment of broadband infrastructure. By the end of the year 2008, the European Commission decided to raise no objections against the initiative allowing the Bavarian government to support each broadband deployment project in rural areas with aid of up to $€ 200,000$.

However, after the state election in 2008, the Bavarian government decided in its coalition negotiations to increase the maximum amount of aid to $€ 500,000$ per municipality project. The respective proposal was approved by the European Commission on 19 May 2009. Due to the large number of subsequent applications by the majority of Bavarian municipalities, the government later decided to extend the program until the end of 2011 allowing all interested municipalities to apply for funding. Eventually, 1,300 municipalities received approval for funding by the end of 2011, i.e., about 63 percent of all Bavarian municipalities. The total funding amount provided by the public authorities added up to $€ 107.6$ million, i.e., about $€ 83,000$ per aided municipality. Funding was granted for feasibility studies and planning activities as well as for closing the profitability gap for network infrastructure deployment.

Further information on the economic geography of broadband state aid is provided in Figure 1 below by plotting the State of Bavaria as well as the state aid status of all of its municipalities - with 'white' indicating municipalities that did not receive any aid, 'light blue' flagging municipalities that received aid in the 2008 to 2009 period and 'dark blue' showing all municipalities that received broadband aid in the 2010 to 2011 period. As revealed by Figure 1 , the white areas are distributed all over Bavaria and do not show apparent concentrations in particular areas of the State. 


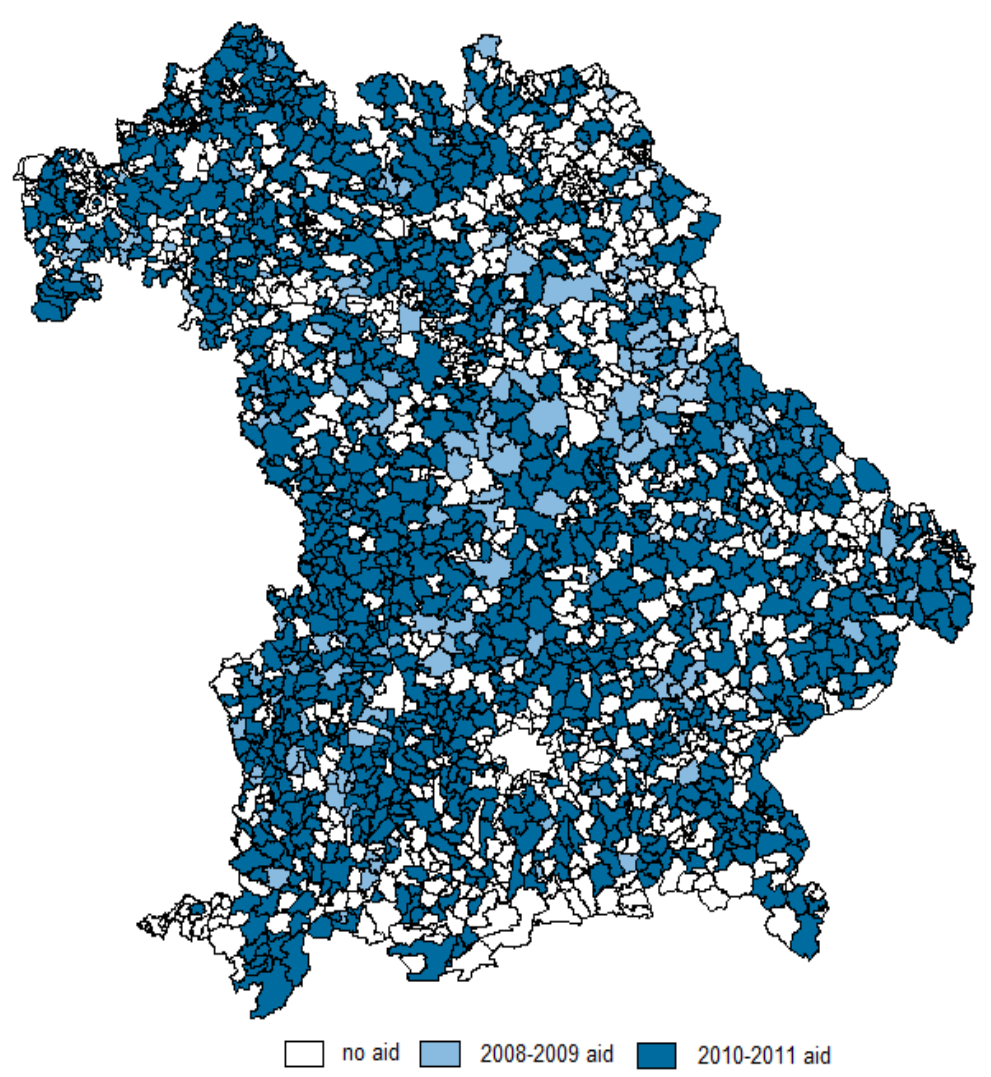

Figure 1: Aided and non-aided municipalities in Bavaria

Data Source: "Schnelles Internet für Bayern"

In our empirical investigation below, we focus on the impact of broadband state aid granted by the State of Bavaria in the 2010 to 2011 period - basically because 87 percent of all aided municipalities received funding in this second aid period (marked in dark blue in Figure 1). Generally, the event window has to be long enough such that changes in broadband infrastructure deployment related to state aid can be captured; however, it must also be short enough to avoid confounding effects from other changes that are not under control.

Accordingly, in defining our treatment period of 2010 and 2011, we excluded 171 municipalities (i.e., about 8 percent of all Bavarian municipalities) to which state aid was granted during the first state aid program from 2008 to 2009 (marked in light blue in Figure 1). Overall, our sample consists of 1885 municipalities, from which 1129 are in the treatment and 756 are in the control group of untreated municipalities.

As the deployment of broadband infrastructure is rather time-consuming and subject to technical complexities related to network planning, regulatory and legal permissions (such as rights of way and, in particular, the state aid approval procedures themselves) as well as other institutional rigidities (such as negotiations with property owners), it can take place only gradually (see Briglauer, 2015). Accordingly, we do not expect any substantial network deployment activities in the same year when state aid was approved by the government. 


\section{Empirical strategy}

We employ a two-stage empirical approach that, in the first stage, aims at identifying the effect of state aid on broadband coverage in Bavarian municipalities that received approval (treatment) in the period from 2010 to 2011 (effectivity question). In order to achieve this, we employ a standard difference-in-differences (DiD) estimator as well as conditional DiD which is based on a matched sample of aided and non-aided municipalities (Section 4.1). ${ }^{10}$ In the second stage, we identify the effect of state-aid induced broadband deployment on employment using a two-stage-least-squares (2SLS) instrumental variable (IV) estimation method (Section 4.2, efficiency question).

\subsection{The impact of state aid on broadband deployment}

In order to quantify the effect of state aid on broadband deployment, we are first interested in estimating the following static equation (super indexed $s$ ) on the basis of municipality-level panel data:

$$
\text { (1) } \quad b b_{-} h h_{i t}^{q}=\alpha^{s q}+\beta_{1}^{s q} D_{2}+\beta_{2}^{s q} D_{1} D_{2}+\boldsymbol{X}_{i t}^{D i D} \beta_{3}^{s q}+\theta_{i}^{s q}+\varepsilon_{i t}^{q}
$$

The outcome variable, $b b_{-} h h_{i t}^{q}$, measures the share of household broadband coverage (i.e., availability on the supply side and not subscriptions on the demand side) in municipality $i$ and in year $t$ at various levels of bandwidth quality, super indexed $q . \theta_{i}^{S}$ captures municipalityspecific fixed effects and $\varepsilon_{i t}$ represents the error term of the static specification. Including municipality fixed effects already captures a large share of the variation in broadband coverage, since most of the supply and demand factors show low variation over time (see also Akerman et al., 2015, p. 1796). Equation (1) is estimated separately for the different quality levels. $D_{1}$ is a binary variable that indicates whether a municipality received treatment (state aid approved, $D_{1}=1$ ) in the funding period from 2010 to 2011 . The variable $D_{2}$ is also of binary nature and signals whether an observation belongs to the pre- or post-treatment period. $D_{2}$ is equal to one for the period from 2012 to 2014 as the corresponding observations were measured after the treatment, and zero otherwise. The coefficient of interest, however, is $\beta_{2}^{S}$, the coefficient of the interaction term, $D_{1} D_{2}$, which is equal to one if the observation was measured after the treatment period and the observation was treated. Hence, the DiD coefficient, $\beta_{2}^{S}$, directly captures the average treatment effect over the years 2012 to 2014 . The vector $\boldsymbol{X}_{i t}^{\text {DiD }}$ contains the following list of time-varying covariates (discussed further in Section 5 below):

- $\quad$ Socio-structural: Working age structure, share of females

- Geo-structural: Population density, accessibility of motorways and regional cities

- $\quad$ Economical: Share of medium-sized firms, share of large firms, share of gross value added in secondary and tertiary sector

10 Please note that this kind of conditional DiD estimator relaxes the key identifying assumptions as it combines both the advantage to abandon the linear assumption when controlling for observables and to control for unobservables exploiting the panel dimension of the data (see Heckman et al., 1998). 
- $\quad$ Political: Vote shares of CSU ('conservatives') and SPD ('democrats') political parties in municipal elections

Second, as we have several time periods available, we can model the dynamics of the treatment effect more flexibly. The 'dynamic' (super indexed $d$ ) DiD regression framework for municipality $i$ and year $t$ with quality $q$ is specified analogously to equation (1) and reads as follows:

(2) $\quad b b_{-} h h_{i t}^{q}=\alpha^{d q}+\sum_{t=2012}^{2014}\left(\beta_{1 t}^{d q} D_{t}+\beta_{2 t}^{d q} D_{1} D_{t}\right)+\boldsymbol{X}_{i t}^{D i D} \beta_{3}^{d q}+\theta_{i}^{d q}+\mu_{i t}^{q}$

Instead of one interaction term in the static model, in the dynamic model, we have three interaction terms, one for each year after treatment. In equation (2), $t$ can take three distinct values corresponding to the years 2012 to 2014. Accordingly, instead of one dummy variable capturing the entire period after treatment, in the dynamic model, we include three different dummies controlling for each year after treatment individually. This dynamic specification traces out the full adjustment path and thus relaxes the assumption that the policy impact is immediate or the same in every year.

The key identifying assumption underlying the DiD estimator is that both, the treated as well as the untreated municipalities follow the same trend ('parallel trends assumption'). In our regressions, we include a large number of covariates to control for factors that might lead to different trends across the two groups after treatment. To ensure that the treatment and control group municipalities are even more likely to show the same trend over time, we also relate the DiD estimator to a matched sample obtained from a propensity score matching (PSM) procedure. For PSM we include the same set of controls to capture pre-existing initial conditions measured in 2010 and additionally include the following list of controls where we have pre-treatment information to further address the omitted variable bias at the municipality level:

- $\quad$ Socio-structural: Number of households in 2010

- Geo-structural: Type of municipality in 2010

- $\quad$ Economical: Development of average rents in the years 2007-2009

- Initial broadband conditions: Average annual growth rate in coverage of $1 \mathrm{Mbit} / \mathrm{s}$ in the years 2007 to 2009, availability of 2, 6 and $16 \mathrm{Mbit} / \mathrm{s}$ in 2010

Matching is a non-parametric estimation method and thus one of its main advantages is that it does not rely on a particular specification of functional forms and distributional assumptions about the error term as is the case in ordinary regression methods including DiD regression frameworks. The broadest possible average causal effect is the average treatment effect (ATE) which averages across all municipalities. The ATE represents an estimator that can be applied to a sample drawn from a larger population where each individual observation is considered. However, in most policy contexts, the particular interest is on the ATT for whom the policy treatment was designed. In deciding whether a policy was effective, the focus would then be on those municipalities who received the treatment but not on the average effect of all municipalities (see Heckman et al., 1997). In our case, the focus is thus on ATT, however, we 
calculate both the ATT and the ATE in our treatment analysis as part of our robustness checks. ${ }^{11}$

Identification of the ATT requires that all (pre-treatment) covariates that influence treatment assignment and potential outcomes simultaneously have to be observed meaning that there are no omitted confounding covariates (see Sianesi, 2004). To ensure that causal effects of the main explanatory variables are measured, we address the omitted variable bias at the municipality level by including several time-variant control variables in our empirical analysis. The other main matching assumption, referred to as 'overlap' or 'common support', implies that there is overlap in both groups as for each treated municipalities there is another matched control group with a similar set of covariates

\subsection{Instrumental variable estimation of the impact of broadband infrastructure}

The second stage of our analysis focuses on the impact of broadband infrastructure on different employment-related outcome variables. Broadband infrastructure, however, is not deployed randomly, but likely to be correlated with economic prosperity in a certain region or municipality. Accordingly, broadband infrastructure might be correlated with the error term which yields biased and inconsistent estimates. To address this point, we make use of 2SLS/IV estimation with two-way fixed effects in which we use the interaction term $D_{1} D_{2}$ as the external instrument for broadband coverage. This allows us to identify a causal effect of state aid on the outcome variable as the granting of state-aid solely for the purposes of broadband deployment has no direct or indirect - other than through broadband deployment impact on the outcome variable. Accordingly, the second stage model of our empirical analysis reads as follows:

(3) $Y_{i t}^{I}=\delta+\gamma_{1}{ }^{I q} b b_{-} h h_{i t}^{q}+\boldsymbol{X}_{i t}^{I V} \gamma_{2}{ }^{I q}+\theta_{i}^{I V}+\lambda_{t}^{I V}+\varphi_{i t}^{q}$

where $Y_{i t}^{I}$ is the relevant employment outcome (measured by indicator $I$ ) in municipality $i$ in period $t$. The outcome variable of the first stage, $b b_{-} h h_{i t}^{q}$, is now the main explanatory variable of interest. Accordingly, the coefficient $\gamma_{1}^{I q}$ indicates the impact of broadband coverage on employment outcome variables. Note, however, the estimated coefficients in the employment equations represent the impact of broadband availability on employment outcomes but not the effect related to actual broadband usage. Whereas the former measures the intention-to-treat effect, the latter directly impacts economic outcomes such as employment in particular and is a function of broadband availability. Accordingly, we estimate a reduced form where the estimated coefficients represent a proportional effect which is smaller than the effect via broadband usage (see Czernich, 2014). $\boldsymbol{X}_{i t}^{I V}$ includes the set of covariates used in the first stage as well as education as a major employment specific covariate. $\theta_{i}^{I V}$ and $\lambda_{t}^{I V}$ represent the municipality fixed effects and period effects, respectively, and $\varphi_{i t}^{q}$ is the additive error term. By multiplying the coefficient $\beta_{3}^{s}$ from the first stage with

11 Please also note that the ATT and ATE estimators rest on different identifying assumptions (which are weaker for the ATT estimator, see Cameron and Trivedi 2005, p. 864). 
the coefficient $\gamma_{1}^{I q}$ from the second stage, we can assess the causal effect (reduced form) of the state aid program on the respective outcome variable.

\section{Data}

Our empirical analysis makes use of several separate data sets: the GENESIS database ${ }^{12}$ and the INKAR ${ }^{13}$ database both provide most of our socio-structural, geo-structural, economic and political covariates; the $\mathrm{ACXIOM}^{14}$ data base provides information on the number of freelancers; the 'Schnelles Internet für Bayern' ${ }^{6}$ database and the German Breitbandatlas ${ }^{15}$ provide data on which municipality received state aid as well as broadband coverage. All variable definitions and sources are summarized in Table A.1 in the Annex. Table A.2 provides the summary statistics.

The time window for our analysis ranges from 2010 to 2014. The treatment, i.e., the approval of state aid for broadband deployment, took place between 2010 and 2011. In view of the institutional rigidities described in Section 3, we consider the year 2010 as pre-treatment. We do not evaluate the outcome variables with respect to the year 2011 as it can neither be seen as pre- nor as post-treatment. The years from 2012 to 2014 define our post-treatment period.

\subsection{Broadband availability in Bavarian municipalities}

Broadband availability in the years 2010 to 2014 is measured as the share of households in a municipality that have access to a particular bandwidth quality level. In our analysis, we measure standard broadband with three different levels of download speed, i.e., $\geq 2, \geq 6$, and $\geq 16 \mathrm{Mbit} / \mathrm{sec}$, denoted with $\mathrm{HH} \_2 \mathrm{MB}, \mathrm{HH} \_6 \mathrm{MB}$ and HH_16MB. Since the state aid program was predominantly designed to provide a basic supply of broadband infrastructure, we concentrate on these low to medium speed levels.

Figure 2 illustrates the development of bandwidth levels in our observation period. As shown in the left-hand graph, treated municipalities are developing faster than untreated ones and in the year 2012 overtake the untreated municipalities. The right-hand graph shows the same trend for the observations in the control group (instead of all untreated municipalities). Interestingly, the difference between treated and untreated (control) municipalities in the year 2014 is even larger in the right-hand graph.

12 See https://www.statistikdaten.bayern.de/genesis/online (last accessed on 1 July 2016).

13 See http://www.inkar.de/ (last accessed on 1 July 2016).

14 See http://www.acxiom.de/ (last accessed on 1 July 2016).

15 See http://www.zukunft-breitband.de/Breitband/DE/Breitbandatlas/BreitbandVorOrt/breitband-vor-ort_node. html (last accessed on 1 July 2016). 

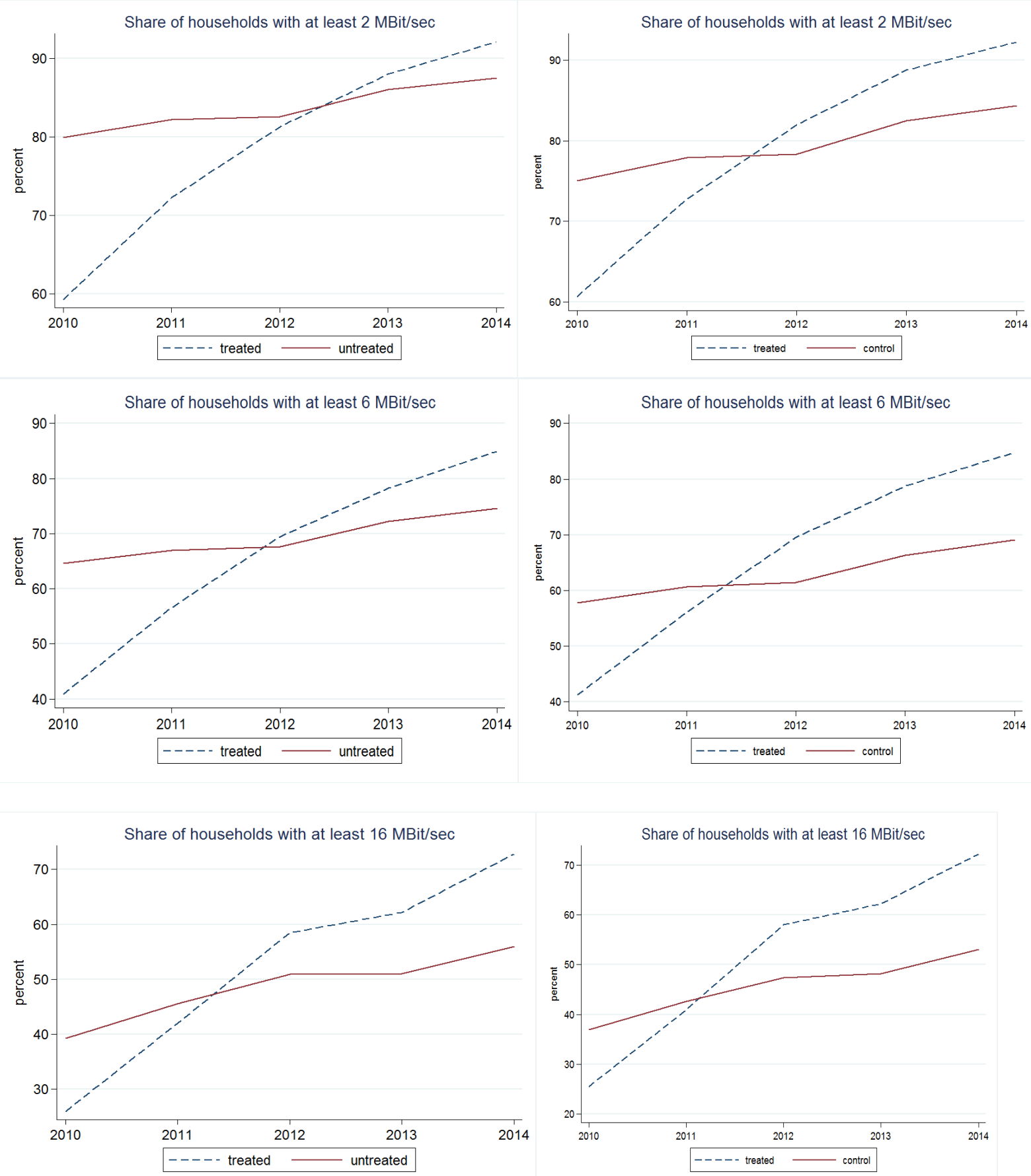

Figure 2: Development of broadband deployment in Bavaria

Data Source: "Breitbandatlas"

\subsection{Employment in Bavarian municipalities}

We measure employment in a municipality by the number of employees with social insurance at place of residence (EMPL_RES) as well as place of work (EMPL_WORK) per 100 residents. The number of employees with social insurance at place of residence measures the number of persons living in a given municipality having a job. The number of employees with social insurance at place of work measures the number of persons working in a given municipality. The variable EMPL_SELF measures the number of self-employed workers and 
freelancers per 100 residents. Finally, we are also able to examine the impact of basic broadband infrastructure on the average workers' annual gross wages (WAGE).

In Figure 3 we show the development of employees with social insurance per 100 inhabitants at place of work and at place of residence. Treated municipalities show fewer employees measured at place of work than untreated municipalities in 2010. However, in 2012 and 2013, treated municipalities are found to overtake the untreated ones. Compared with employees at place of work, the distance between treated and untreated (control) municipalities is substantially larger for employees at place of residence and is more pronounced in 2014 than in 2010. In Figure 4 we depict the development of self-employed and freelancers per 100 inhabitants and the annual gross wages. It appears that treated and untreated municipalities follow rather similar trends. In treated municipalities we observe less self-employed and freelancers than in untreated municipalities. This gap also does not close after the treatment period. A comparable development is found in the graph plotting annual gross wages.
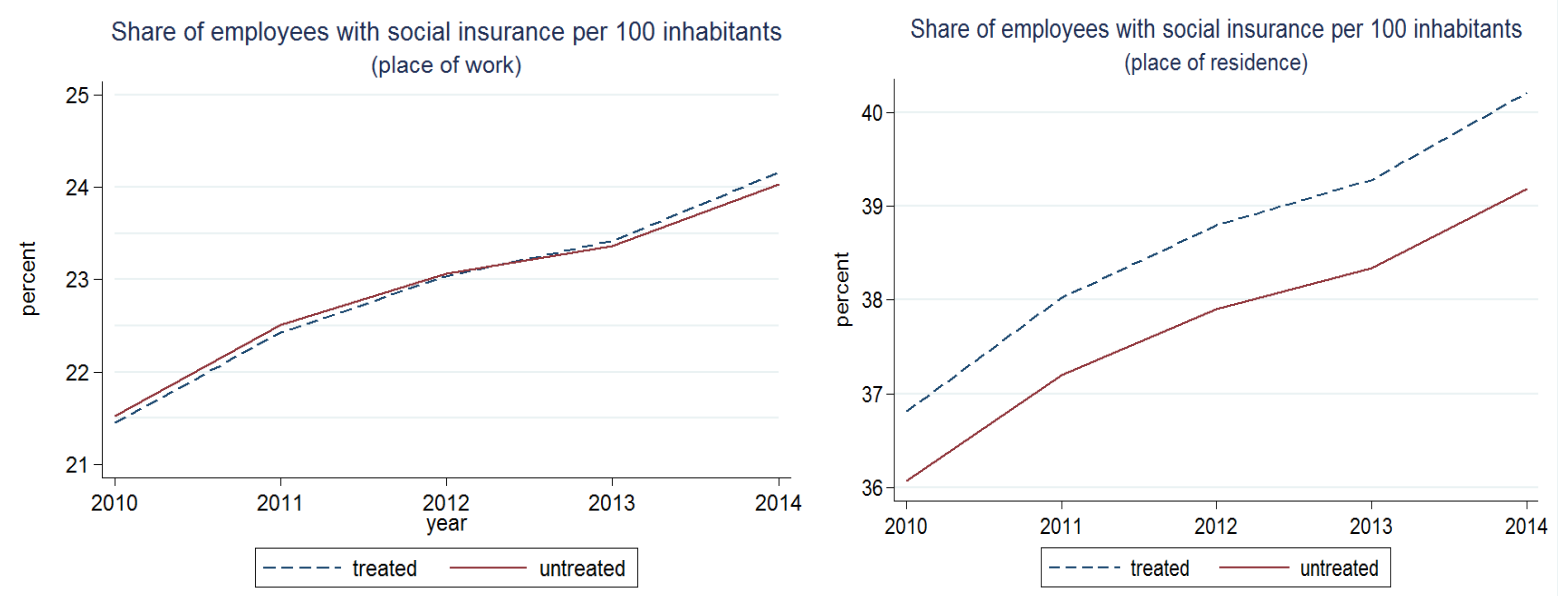

Figure 3: Development of employees with social insurance at place of work (left panel) and residence (right panel) in Bavaria

Data Source: GENESIS
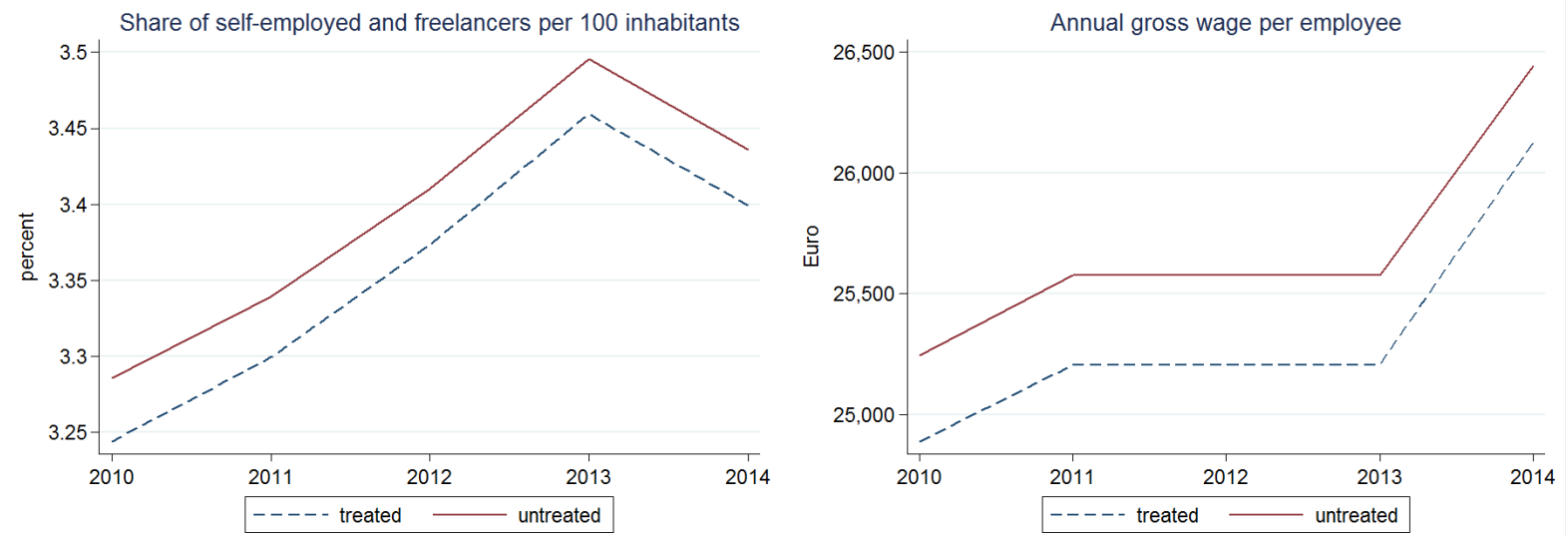

Figure 4: Development of self-employed (left panel) and gross annual wages (right panel) in Bavaria

Data Source: AXCIOM and GENESIS 


\subsection{Main explanatory variables and further covariates}

Our main explanatory variable for the treatment analysis on the first stage is a binary indicator $\left(D_{1}\right)$ which measures whether a municipality received state aid between 2010 and 2011. We expect that municipalities receiving state aid have increased access to broadband which should become reinforced due to adjustment costs in the subsequent years.

Regarding the second stage of our analysis, the main explanatory variable of interest is the available broadband infrastructure stock as described in Section 5.1. We expect that a higher broadband infrastructure stock induces positive externalities on major sectors of the economy including local labor markets. Accordingly, we expect that broadband deployment also comes along with positive net employment effects in aided municipalities.

We distinguish five sets of covariates:

Covariates controlling for the socio-structural dimension of a municipality are alongside with the proportion of working people (WORKING_AGE) and the share of females (FEMALE) in a municipality. The age structure is measured by the share of people between 18 and 65 .

The next set of covariates controls for geo-structural characteristics of a municipality. We include a municipality's population density (POP_DENS) which captures average broadband deployment costs - characterized by so-called 'economies of density' leading to considerably higher costs in rural areas. Furthermore, densely populated areas tend to have thicker labor markets for relevant IT skill complementarities (see Forman et al. 2012). Transport accessibility is measured as the average journey time (by car) in minutes to the next public accessibility point in terms of the next motorway (ACC_MOTOR) and the next regional metropolitan area (ACC_CITIES). Rural municipalities with good public accessibility might grow faster and attract funding more easily in view of a lower profitability gap. Very remote municipalities in, e.g., alpine regions most likely, however, did not receive aid at all, as average deployment costs are simply too high to fall under the treatment scheme.

We further collected economical covariates along the following dimensions: the size and the business segment of the local companies. Specifically, we include the share of medium (FIRM_MED) and large firms (FIRM_BIG) as well as the gross value added (GVA) in the secondary (GVA_SEC) and tertiary sector (GVA_TER), i.e., we can control for how important the production and service sectors are in comparison to the primary sector. Municipalities with a higher number of large firms and more pronounced secondary and tertiary sectors might have greater impact when claiming state aid. At the same time, local politicians might have an incentive to support economically underdeveloped areas in particular.

We further control for the political dimension by incorporating the outcome of the last communal election. In particular, we control whether municipalities led by one of the two main parties in Bavaria, the Christian Social Union (CSU) and the Social Democratic Party (SPD), have been more successful in receiving aid. These variables can also be regarded as a proxy for how well a municipality is managed. 
Our employment-specific control variable captures education (EDUC) measured as the share of school leavers with a higher education entry qualification in the total number of school leavers.

Finally, in PSM we also consider the initial conditions in the period from 2007 to 2010 :

First, we control for the average yearly growth rate of coverage of $1 \mathrm{Mbit} / \mathrm{sec}$ between 2007 and 2009 (GR_1MB). Second, we include the share of households that had access to at least 2, 6 and $16 \mathrm{Mbit} / \mathrm{sec}$ in the year 2010 (HH_2MB, HH_6MB, HH_16MB). This ensures that pre-treatment units followed the same trend in the years directly preceding the granting of state aid and were - with respect to broadband availability - on the same initial level. Further covariates used for PSM are the number of households $(\mathrm{HH})$ and the type of a municipality (TYPE_X) which provides a classification between 1 and 5 indicating a municipality's degree of urbanization depending on the local infrastructure. Both covariates are available for the year 2010. The latest outcome of the communal election in Bavaria before our funding period refers to the year 2008. Finally, we have information on the average annual growth in rents per square meter (RENT) over the time period from 2007 to 2009.

\section{Estimation results}

In this section, we present our main results of the treatment analysis based on DiD approaches. Section 6.1 first discusses the results of the PSM procedure which serves as a prerequisite to delineate the sample for conditional DiD. Subsequently, we present the results of basic and conditional DiD in Section 6.2 (effectivity question). In both DiD variants, we analyze the immediate, i.e., static impact as well as dynamic effects of state aid policies. In Section 6.3, we then discuss the main IV estimation results as regards the impact of broadband infrastructure on employment (efficiency question).

\subsection{Propensity score matching}

Before coming to our DiD and IV estimation, we aim at making treated and untreated municipalities as similar as possible so that the common trend assumption is likely to hold. We do this by propensity score matching (PSM). In PSM, we consider the initial conditions in a municipality in the period from 2007 to 2010. First, we control for the average yearly growth rate of broadband coverage of $1 \mathrm{Mbit} / \mathrm{sec}$ between 2007 and 2009 (GR_1MB). Second, we include the share of households that had access to at least 2, 6 and $16 \mathrm{Mbit} / \mathrm{sec}$ in the year 2010 (HH_2MB, HH_6MB, HH_16MB). This ensures that pre-treatment units followed the same trend in the years directly preceding the granting of state aid and were with respect to broadband availability - on the same initial level. Further covariates used for PSM are the number of households (HH), population density (POP_DENS), share of persons in working age (WORKING_AGE) and share of females (FEMALE) as well as the type of a municipality (TYPE_X). These covariates are available for the year 2010. The latest outcome of the communal election in Bavaria before our funding period refers to the year 2008. Here, we include the shares of votes gained by the two most popular parties CSU and SPD. Finally, we have information on the number of medium (FIRM_MED) and large firms (FIRM_BIG), the share of gross value added in the secondary (GVA_SEC) and tertiary sector (GVA_TER), the accessibility of motorways (ACC_MOTOR) and cities (ACC_CITIES), and the average 
annual growth in rents per square meter (GR_RENT) over the time period from 2007 to 2009. We apply nearest neighbors matching with two and three nearest neighbors.

Table 1 is a balancing table and shows the mean differences in broadband availably and covariates between treated and control municipalities before and after matching. We apply ordinary two-sample $t$-tests to check the balancing properties of our matching procedure. The tests examine whether the differences in means are different in treated and untreated groups before and after matching $\left(\mathrm{H}_{0}\right.$ : 'means are equal for both groups'). For obvious reasons, matching is designed to ensure that for units with a similar propensity score the assignment to treatment is random and independent of the covariates. If this is satisfied then municipalities with a similar propensity score must have the same distribution of covariates independently of the treatment status. This balancing condition is testable through differences in means for each covariate. Table A.3 reports the mean tests applied to the whole sample, i.e., before matching is conducted. As expected, almost all means of the covariates are significantly different between treated municipalities $(\mathrm{N}=1129)$ and untreated municipalities $(\mathrm{N}=756)$. In contrast, one can infer from Table 1 that all covariates are well balanced after matching which holds for both control groups ( $\mathrm{NB}=2$ and $\mathrm{NB}=3$ ). Therefore, and in line with the above tests, we are confident that our matching procedure was successful in identifying valid counterfactuals for the group of treated (i.e., state aid-receiving) municipalities.

Table A.4 reports the results of the probit regression of the PSM approach assessments of the quality of the matching procedure refer to the performance measures of the probit model. The Pseudo $R^{2}$ measures the explanatory power of the covariates and should be significantly lower after the matching procedure (see Sianesi 2004). Indeed, comparing the Pseudo $R^{2}$ in Table A.4 (0.158) with the respective value of the probit regression after matching based on the sample of treated units and counterfactuals $(0.003 \text { for } \mathrm{NB}=2 \text { and } 0.003 \text { for } \mathrm{NB}=3)^{16}$ indicates that the systematic differences between both groups decreased substantially after controlling for covariates. Similarly, one can compare likelihood ratio tests on the joint significance of all covariates in the probit model before and after matching. As required, the null hypothesis ('all covariates are jointly insignificant') is rejected before ( $p=0.000)$ but not after matching ( $p=0.917$ for $\mathrm{NB}=2$ and $p=0.875$ for $\mathrm{NB}=3$ ).

16 The underlying probit regressions are available from the authors upon request. 
Table 1: Mean difference tests after matching with unequal variances

\begin{tabular}{|c|c|c|c|c|c|c|c|c|}
\hline & \multirow{2}{*}{\multicolumn{2}{|c|}{$\begin{array}{l}\text { Aid-receiving } \\
\text { municipalities } \\
\mathrm{N}=1077 \\
\end{array}$}} & \multirow{2}{*}{\multicolumn{2}{|c|}{$\begin{array}{l}\text { Selected control } \\
\text { group (2NB) } \\
\mathrm{N}=2,154(547)\end{array}$}} & \multirow{2}{*}{\multicolumn{2}{|c|}{$\begin{array}{l}\text { Selected control } \\
\text { group (3NB) } \\
\mathrm{N}=3,231(616)\end{array}$}} & \multirow{2}{*}{\multicolumn{2}{|c|}{$\begin{array}{c}\text { Results of } t \text {-test } \\
\text { on mean } \\
\text { differences }\end{array}$}} \\
\hline & & & & & & & & \\
\hline & mean & S.D. & Mean & S.D. & Mean & S.D. & $2 \mathrm{NB}$ & $3 \mathrm{NB}$ \\
\hline \multicolumn{9}{|l|}{ Covariates } \\
\hline HH_2MB_2010 & 60.94 & 32.11 & 60.70 & 35.94 & 59.64 & 35.89 & & \\
\hline HH_6MB_ 2010 & 41.65 & 33.33 & 41.00 & 36.87 & 41.35 & 36.68 & & \\
\hline HH_16MB_2010 & 25.81 & 28.99 & 26.82 & 32.29 & 26.68 & 31.51 & & \\
\hline GR_RENT & 0.06 & 0.03 & 0.06 & 0.03 & 0.06 & 0.04 & & \\
\hline GR_1MB & 3.22 & 3.97 & 5.50 & 5.41 & 3.37 & 3.40 & & \\
\hline $\mathrm{HH}$ & 2.39 & 8.53 & 2.06 & 3.80 & 2.19 & 5.59 & & \\
\hline WORKING_AGE & 62.92 & 1.94 & 62.89 & 1.98 & 62.89 & 2.04 & & \\
\hline FEMALE & 50.02 & 1.49 & 50.04 & 1.41 & 50.00 & 1.51 & & \\
\hline POP_DENS & 160.64 & 189.61 & 161.93 & 194.32 & 161.10 & 219.97 & & \\
\hline TYPE_1 & 0.00 & 0.04 & 0.00 & 0.02 & 0.00 & 0.04 & & \\
\hline TYPE _2 & 0.03 & 0.17 & 0.03 & 0.17 & 0.03 & 0.16 & & \\
\hline TYPE_3 & 0.08 & 0.27 & 0.07 & 0.26 & 0.08 & 0.27 & & \\
\hline TYPE_4 & 0.27 & 0.44 & 0.29 & 0.45 & 0.26 & 0.44 & & \\
\hline TYPE_5 & 0.62 & 0.49 & 0.61 & 0.49 & 0.63 & 0.48 & & \\
\hline FIRM_MED & 14.85 & 3.64 & 15.06 & 3.85 & 14.85 & 3.84 & & \\
\hline FIRM_BIG & 2.40 & 0.89 & 2.43 & 0.89 & 2.39 & 0.91 & & \\
\hline GVA_SEC & 37.46 & 9.34 & 37.32 & 10.49 & 37.63 & 10.89 & & \\
\hline GVA_TER & 60.75 & 9.42 & 60.90 & 10.51 & 60.56 & 10.87 & & \\
\hline $\mathrm{CSU}$ & 0.24 & 0.20 & 0.24 & 0.21 & 0.24 & 0.22 & & \\
\hline SPD & 0.10 & 0.12 & 0.10 & 0.13 & 0.10 & 0.13 & & \\
\hline ACC_MOTOR & 15.29 & 11.09 & 15.38 & 9.91 & 15.27 & 10.09 & & \\
\hline ACC_CITIES & 31.53 & 14.79 & 30.83 & 14.42 & 31.01 & 14.61 & & \\
\hline \multicolumn{9}{|l|}{ Outcome var. } \\
\hline HH_2MB_ 2012 & 81.90 & 24.34 & 65.99 & 33.70 & 65.35 & 34.15 & $* * *$ & $* * *$ \\
\hline HH_2MB_ 2013 & 88.63 & 18.56 & 71.70 & 30.90 & 71.05 & 31.32 & $* * *$ & $* * *$ \\
\hline HH_2MB_2014 & 92.22 & 14.07 & 75.12 & 29.44 & 74.21 & 30.09 & $* * *$ & $* * *$ \\
\hline HH_6MB_ 2012 & 69.63 & 30.24 & 47.03 & 36.45 & 46.93 & 36.58 & $* * *$ & $* * *$ \\
\hline HH_6MB_2013 & 78.69 & 25.92 & 52.56 & 35.98 & 52.19 & 36.01 & $* * *$ & $* * *$ \\
\hline HH_6MB_2 2014 & 84.74 & 20.66 & 57.05 & 36.42 & 56.46 & 36.56 & $* * *$ & $* * *$ \\
\hline HH_16MB_2012 & 58.01 & 31.30 & 36.25 & 32.83 & 36.22 & 32.84 & $* * *$ & $* * *$ \\
\hline HH_16MB_2013 & 62.13 & 30.09 & 38.76 & 34.15 & 38.37 & 33.94 & $* * *$ & $* * *$ \\
\hline HH_16MB_2014 & 72.16 & 26.89 & 44.79 & 36.23 & 44.31 & 36.03 & $* * *$ & $* * *$ \\
\hline
\end{tabular}

${ }^{*} p<0.10,{ }^{* *} p<0.05,{ }^{* * *} p<0.01 . \mathrm{H}_{0}$ : equal means for both groups. As the nearest neighbor matching procedure is performed with replacement, we impose Lechner's variance approximation (Lechner, 2001). Due to the lack of common support, 52 municipalities had to be dropped resulting in a number of 1,077 treated municipalities. With two and three nearest neighbors, this corresponds to 2,154 or 3,231 observations in the control group, respectively. The numbers in parentheses in the heading of Table 1 indicate the number of real municipalities used in PSM. As we have less untreated than treated municipalities, we reuse municipalities in the control group for several treated municipalities. 


\subsection{First stage: The impact of state aid on broadband deployment}

Table 2: shows the estimation results of the static and dynamic DiD models on the basis of the whole (columns (1), (3) and (5)) and the matched sample of treated and untreated municipalities (columns (2), (4) and (6)). In order to take into account the fact that several non-treated municipalities are overrepresented in the matched sample due to replacement, we also applied weights in the DiD estimation. If a municipality from the control group was a neighbor for several treated municipalities, it accordingly receives a proportionally higher weight in the DiD estimation. Table 2: reports the average treatment effect (ATE) which averages across all municipalities (whole sample) and the average treatment effect on the treated (ATT) for the matched sample.

In the static model, the treatment effect is averaged over the years following the treatment. For instance, the ATT in column (2) is $\sim 16.76$, meaning that within the treatment group, the fraction of households which had access to at least $2 \mathrm{Mbit} / \mathrm{sec}$ increased by 16.76 percentage points after the treatment. Regarding the ATT for 6 and $16 \mathrm{Mbit} / \mathrm{sec}$, the ATT is - with about 20 percentage points - even larger. Generally, the treatment effects are higher for 6 and 16 $\mathrm{Mbit} / \mathrm{sec}$ quality levels in all specifications. These findings appear to be reasonable as bandwidth of $>=2 \mathrm{Mbit} / \mathrm{sec}$ represented a very elementary quality level in the post-treatment period. Hence, it appears likely that funding was used to realize higher broadband levels, since in 2010 broadband with $2 \mathrm{Mbit} / \mathrm{sec}$ bandwidth has already been widely dispersed even in treated municipalities.

The dynamic model reports the ATE/ATT for each year after treatment individually. All coefficient estimates indicate that there is a highly significant and positive treatment effect underlying all quality levels of broadband infrastructure. However, since some municipalities received treatment later, i.e., in 2011 instead of 2010, and in view of the gradual infrastructure deployment process, it appears unlikely that corresponding treatment effects have already been materialized completely within the first year of policy assessment, i.e., in 2012. Due to adjustment costs, potential impacts are rather expected in the following years 2013 to 2014. In line with these expectations, the treatment effect is strictly increasing over the years for each broadband quality level and for both specifications (based on the whole and matched sample only). For instance, for the speed of $6 \mathrm{Mbit} / \mathrm{sec}$, the treatment effect for the matched sample (column (4)) increases from $\sim 18.75$ percentage points in 2012 to $\sim 23.52$ percentage points in 2013 and to $\sim 27.21$ percentage points in 2014 . 
Table 2: First stage DiD estimation results

\begin{tabular}{|c|c|c|c|c|c|c|}
\hline $\begin{array}{l}\text { Dep. var.: } \\
\text { Sample: }\end{array}$ & $\begin{array}{c}(1) \\
\text { HH_2MB } \\
\text { Whole }\end{array}$ & $\begin{array}{c}(2) \\
\text { HH_2MB } \\
\text { Matched \& } \\
\text { Weighted }\end{array}$ & $\begin{array}{c}\text { (3) } \\
\text { HH_6MB } \\
\text { Whole }\end{array}$ & $\begin{array}{c}\text { (4) } \\
\text { HH_6MB } \\
\text { Matched \& } \\
\text { Weighted }\end{array}$ & $\begin{array}{c}(5) \\
\text { HH_16MB } \\
\text { Whole }\end{array}$ & $\begin{array}{c}\text { (6) } \\
\text { HH_16MB } \\
\text { Matched \& } \\
\text { Weighted }\end{array}$ \\
\hline $\begin{array}{l}\text { Static Model } \\
\text { ATE/ATT }\end{array}$ & $\begin{array}{c}17.1569^{* * *} \\
(23.39)\end{array}$ & $\begin{array}{c}16.7563^{* * *} \\
(22.04)\end{array}$ & $\begin{array}{c}23.7151^{* * *} \\
(27.82)\end{array}$ & $\begin{array}{c}23.2355^{* * *} \\
(25.71)\end{array}$ & $\begin{array}{c}20.9038^{* * * *} \\
(23.76)\end{array}$ & $\begin{array}{c}20.2103^{* * *} \\
(19.88)\end{array}$ \\
\hline $\begin{array}{l}\text { Dynamic Model } \\
\text { ATE/ATT } 2012\end{array}$ & $\begin{array}{c}13.8541^{* * *} \\
(19.63)\end{array}$ & $\begin{array}{c}13.6111^{* * *} \\
(18.56)\end{array}$ & $\begin{array}{c}18.9725^{* * *} \\
(22.29)\end{array}$ & $\begin{array}{c}18.7469^{* * *} \\
(21.36)\end{array}$ & $\begin{array}{c}16.1000^{* * *} \\
(17.53)\end{array}$ & $\begin{array}{c}15.4308^{* * *} \\
(14.48)\end{array}$ \\
\hline ATE/ATT 2013 & $\begin{array}{l}17.4633^{* * *} \\
(21.47)\end{array}$ & $\begin{array}{l}17.2047^{* * * *} \\
(20.79)\end{array}$ & $\begin{array}{c}23.8157^{* * * *} \\
(24.84)\end{array}$ & $\begin{array}{c}23.5227^{* * * *} \\
(23.33)\end{array}$ & $\begin{array}{c}20.5130^{* * *} \\
(20.41)\end{array}$ & $\begin{array}{c}19.9361^{* * *} \\
(17.25)\end{array}$ \\
\hline ATE/ATT 2014 & $\begin{array}{c}20.1909^{* * * *} \\
(22.54)\end{array}$ & $\begin{array}{c}19.3537^{* * *} \\
(21.05)\end{array}$ & $\begin{array}{c}28.3151^{* * * *} \\
(26.56)\end{array}$ & $\begin{array}{c}27.2138^{* * * *} \\
(24.16)\end{array}$ & $\begin{array}{c}26.4073^{* * * *} \\
(22.62)\end{array}$ & $\begin{array}{c}25.2467^{* * * *} \\
(19.24)\end{array}$ \\
\hline \# Obs. & 9,425 & 8,120 & 9,425 & 8,120 & 9,425 & 8,120 \\
\hline
\end{tabular}

\subsubsection{Assessing the parallel trend assumption}

The key identifying assumption underlying the DiD estimator is the parallel trend assumption. Although the latter is not directly testable, the assumption can be investigated using pretreatment data for both groups of treated and untreated municipalities. Figure 5 provides strong visual evidence of a common underlying trend for the pre-treatment period from 2005 to 2009 where data is available for $1 \mathrm{Mbit} / \mathrm{sec}$ broadband coverage. Moreover, if we compare the left-hand and right-hand graph, we can infer that the remaining differences between treated and untreated municipalities are even further reduced if we focus on matched municipalities only (right-hand graph). This provides a reasonable justification for our preference of the conditional DiD approach on the basis of the matched sample.
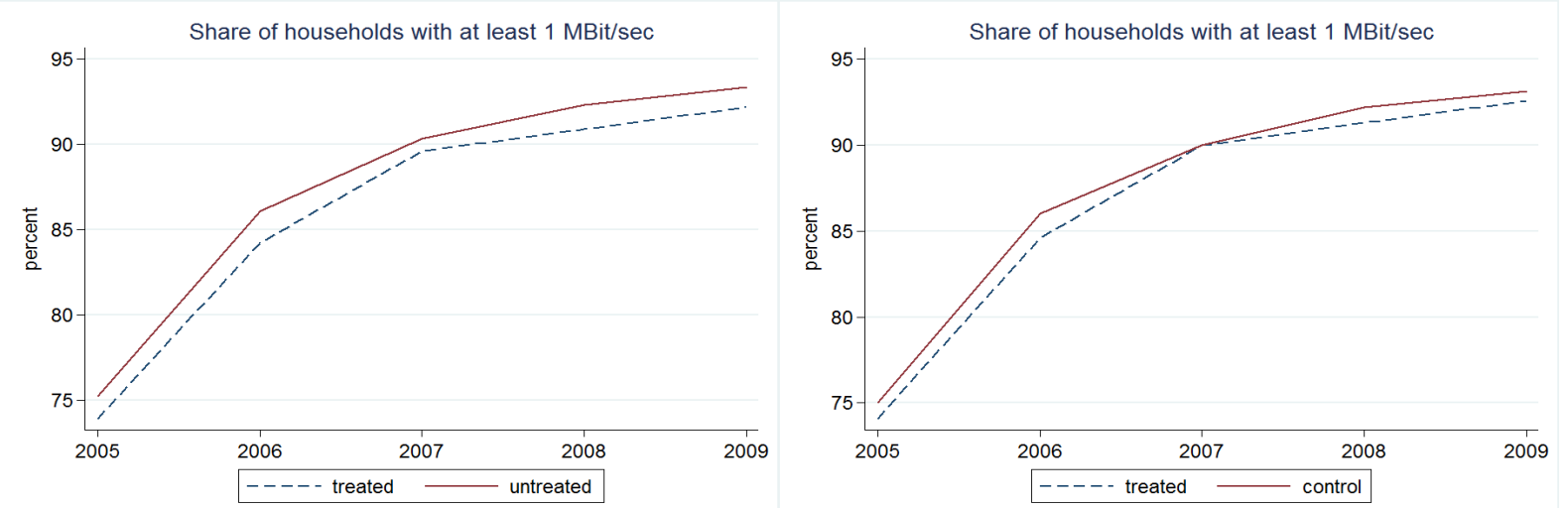

Figure 5: Trends in years preceding treatment for all (left panel) and matched municipalities only (right panel)

Data Source: "Breitbandatlas"

From Figure 5 we also infer that there is no apparent evidence of Ashenfelter's pre-treatment dip (see Ashenfelter, 1978) for aid-receiving municipalities - which might have occurred in view of expectations related to the institutional design and gradual development of the 
funding schemes in Bavaria. However, on the basis of the visual evidence in Figure 5, we can conclude that potential crowding-out effects and overestimation bias should be of secondary importance (if relevant at all). However, in the beginning of the pretreatment period (2010) the observed substantial differences in higher bandwidth levels (Figure 2) suggest some differences in pretreatment trends. Accordingly, we also control for higher bandwidth levels in 2010 in constructing the control group in PSM.

\subsubsection{Assessing the treatment effect with PSM}

We further investigate whether the treatment effects are similar on the basis of a pure PSM procedure which rests upon a different key identifying assumption. Whereas PSM does not require parallel trends, it assumes that conditional on pre-treatment outcomes confounding unobservables are irrelevant ('selection is on observables').

The lower part of Table 1 reports the broadband outcome values for aid-receiving municipalities and different control groups with two (2NB) and three (3NB) nearest neighbors. The differences in average outcome variables of the treated municipalities are statistically significant according to two-sided $t$-tests throughout all definitions and for both counterfactual groups. For instance, the treatment effect is $81.90-65.99=15.91$, if we compare the $2 \mathrm{Mbit} / \mathrm{sec}$ broadband coverage of the treated municipalities with the counterfactual group with 2 nearest neighbors in the year 2012. The respective value is quite similar to the respective DiD coefficient reported in Table 2: (13.85 for the whole and 13.61 for the matched \& weighted sample) - which also applies to the other bandwidth quality levels for both control groups: DiD and PSM based point estimates range from 13.85 to 28.31 (Table 2:) and 12.19 to 28.28 (Table A.6), respectively. From Table A.6 we also see that estimated ATE and ATT again become more effective if we allow for a longer post-treatment period and for higher bandwidth levels.

Overall, treatment analysis on the basis of PSM points to rather similar estimates in terms of magnitude, dynamics and bandwidth levels providing further arguments for the robustness of our first stage estimation results.

\subsection{Second stage: The impact of broadband deployment on employment}

The second stage of our empirical analysis examines the impact of broadband deployment on employment-related outcome variables which are reported in Table 3 in columns (1a)-(4c). ${ }^{17}$ The employment variables in columns (1a)-(3c) are measured as a fraction of 100 residents, whereas average workers' gross wages in columns (4a)-(4c) are measured in $€$ per year. Similar to Section 6.2, we report the estimation results in Table 3 on the basis of the whole as well as matched and weighted samples.

The broadband coverage in our model is endogenous with respect to the share of employees at place of residence (EMPL_RES) as well as for the share of employees at place of work (EMPL_WORK) as the Durbin-Wu-Hausman (DWH) tests reject the null hypothesis of broadband coverage being an exogenous variable in columns (1a)-(2c) for all broadband

\footnotetext{
${ }_{17}$ The estimation results for the full models are available from the authors upon request. For columns (1a)-(1c), the full specifications can be found in the Table A.7.
} 
quality levels. In turn, this is not the case for the other outcome variables (EMP_SELF and WAGE). OLS estimates for the full specifications of all employment outcomes are reported in Table A.8 and A.9. to deal with endogeneity underlying the specifications in columns (1a)(2c), we employ the interaction term $\left(D_{1} D_{2}\right)$ of the first stage as our source of exogenous variation. First stage $F$-statistics of excluded instruments and the Cragg-Donald Wald (CDW) $F$-statistic, which clearly exceeds the IV critical value by Stock and Yogo (2005) for all dependent variables and quality levels, suggest that our instrument is strong and explains the broadband coverage very well.

As revealed by Table 3, with the exception of the employees measured at the place of residence variable (EMPL_RES), we do not find any significantly positive impact of broadband coverage on employment outcome variables. ${ }^{18}$ This finding is at least partly in line with existing empirical evidence also struggling to find supportive evidence for overall significant labor market effects.

Our results suggest that the benefit of increasing broadband coverage in rural areas is visible only with respect to employment measured at place of residence. Taking, for example, the coefficient of HH_6MB (0.0062) in column (1b) and multiplying it with the coefficient from the first stage (23.2355 in Table 3) yields an overall value of 0.144 , suggesting that the number of employees with social insurance at place of residence increased by about 0.14 percent points. Multiplied with the average size of treated municipalities in the pre-treatment year 2010 (50.0420) results in 7.2091, meaning on average about 7 additional persons with jobs with social insurance in each municipality that received the state aid. Multiplying this result with the total number of municipalities that received aid (1129) results in 8,139 additional jobs at place of residence. This key result suggests that households and the respective individuals remain in (or move to) rural areas to live (but not to work) there if basic broadband coverage is present - a finding well in line with recent evidence reported in Ahlfeldt et al. (2016). There, the authors estimate consumers' valuation of broadband speed via house prices and find an elasticity of property prices with respect to internet speed of about 3\%. Their data covers similar ranges of basic broadband connections and underlines the residential importance of broadband (although this effect is more relevant in urban areas).

Last but not least, the fact that increased broadband coverage in treated municipalities did not induce additional jobs measured at place of work - but only jobs at place of residence suggests further that a basic internet infrastructure makes activities such as tele-working or commuting to other (more urban) municipalities more attractive for some of the working age people living in rural areas. In other words, it can be concluded that although we do not find evidence consistent with the hypothesis that state aid has a significant impact on closing the economic divide, it is found to have a significantly positive effect on the closing of the digital divide between urban and rural areas in the German state of Bavaria. Furthermore, if an additional political aim of broadband state aid was seen in the avoidance of a further

18 Table A.8 in the Annex reports significant and positive coefficient estimates also for self-employment (EMPL_SELF) and gross annual wages (WAGE) in OLS specifications; however, the magnitudes of related marginal effects are negligible. 
depopulation of rural areas, our results provide evidence that state aid has significantly contributed reaching this aim. 
Table 3: Second stage IV estimation results

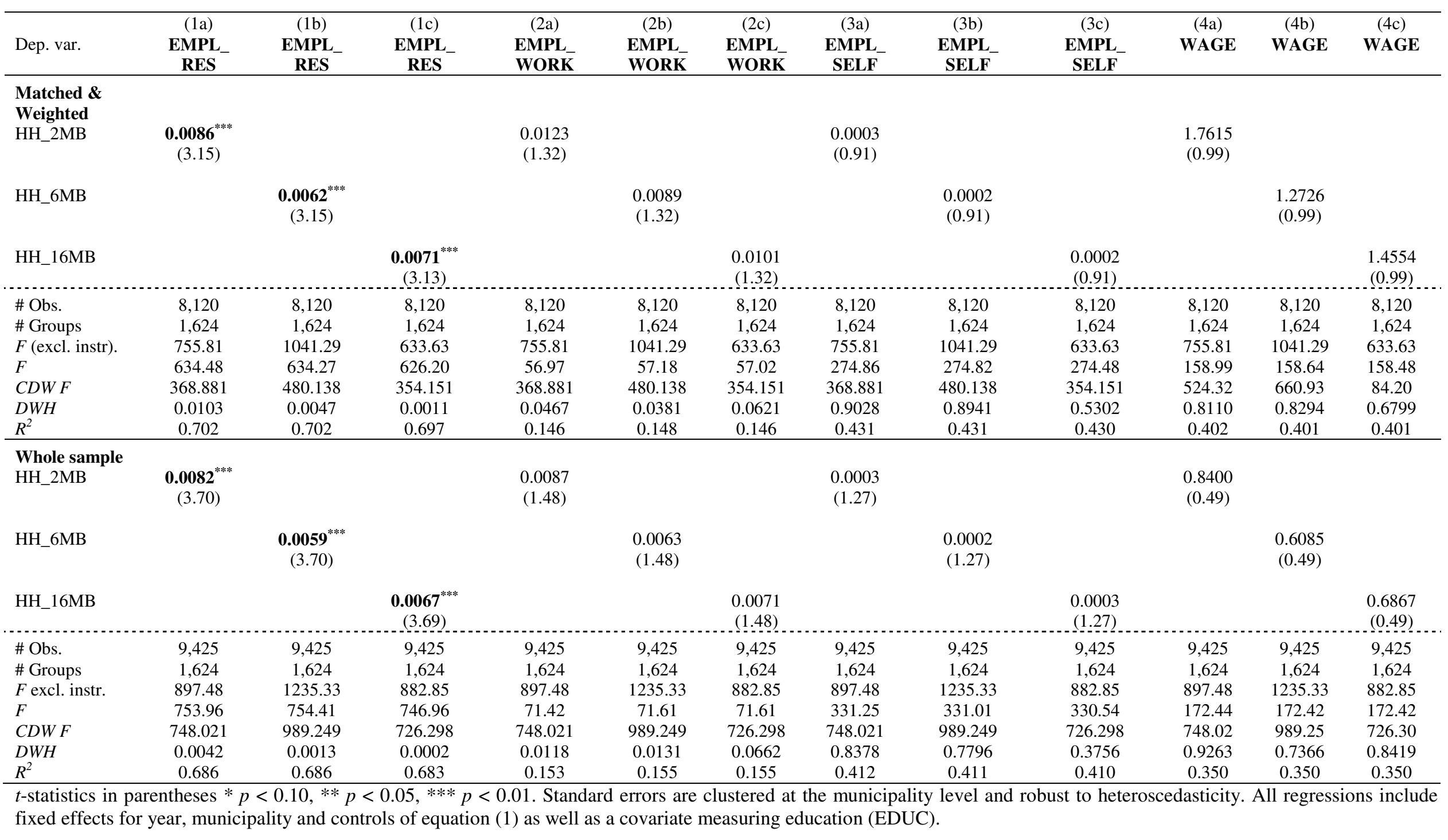




\section{Summary and conclusions}

In May 2012, the European Commission announced its State Aid Modernization (SAM) reform aiming at fostering growth in the internal market through streamlined rules and faster decisions. "State aid control should more effectively target sustainable growth-enhancing policies while encouraging budgetary consolidation, limiting distortions of competition and keeping the single market open" (European Commission, 2012, p. 4). Interestingly, in working towards these goals, the Commission's strategy does not only envisage the identification of common principles for assessing the compatibility of aid with the internal market - in combination with the creation or revision of guidelines and frameworks - but it explicitly includes an ex-post evaluation program as key tool to ensure an effective EU State aid policy (see European Commission, 2014).

In this paper, we provide such an ex-post evaluation for the example of a major state aid program for broadband deployment in rural areas in the German State of Bavaria. Using a unique micro panel data set, we evaluate the causal effect of state aid that was granted in the period from 2010 to 2011 to in sum 1,300 municipalities. Our post-treatment period refers to the years from 2012 to 2014. Using a difference-in-differences estimation strategy on the basis of a matched sample of 1,845 aided and non-aided rural municipalities, we first examined - from an effectivity perspective - the question whether the granting of state aid had the desired direct effect. Our treatment analysis revealed that state aid indeed had an impact on the municipalities treated as they have significantly higher coverage in broadband than comparable non-aided municipalities. In particular, we found that the aided municipalities have - depending on broadband quality - a between 16.8 and 23.2 percent higher broadband coverage than non-aided municipalities. Our results further suggest that the effect of state aid is more pronounced for higher bandwidth levels and that it gains strength over the years after treatment.

Second - from an efficiency perspective - we examined whether the additional broadband coverage also carried over to socially desirable indirect effects in terms of creating new jobs. We found that state aid-induced higher broadband coverage generated significantly positive employment effects with respect to the number of employees at place of residence only. Based on an average bandwidth level ( $6 \mathrm{Mbit} / \mathrm{sec})$, we found that in sum 8,139 additional individuals with social insurance were induced by the broadband state aid program in the years 2010 to 2011 to live in the treated Bavarian municipalities. Furthermore, our empirical results also suggest that more people decided to move into treated municipalities than left these rural areas - indicating that an improved broadband coverage makes these municipalities more valuable places to live. In that sense, the funding program successfully served as a mean to prevent rural municipalities from depopulation - however, it does not impose a measurable effect on the closing of the economic divide in the form of creating new jobs in these municipalities.

Coming back to the main policy-related question - already raised in the title of the article namely whether state aid can help in bridging the digital and economic divide, our empirical results for the State of Bavaria support the conclusion that state aid programs can be an effective instrument to foster broadband deployment in particularly rural areas. When it 
comes to the subsequent efficiency question of such investments, our result of in sum 8,139 additional individuals with social insurance being induced to live in the treated Bavarian municipalities may - on the surface - appear modest compared to the total amount of $€ 107.6 \mathrm{~m}$ of state aid provided by the public authorities to the respective municipalities.

However, a closer look reveals that such a simple comparison of benefits and costs would be superficial for at least two reasons: On the one hand, as it ignores further positive knock-on effects of an improved broadband coverage on, e.g., innovation or economic growth, that are expected to be generated in the longer run. On the other hand, such a simple comparison ignores the additional (counterfactual) costs that would have been created by an accelerating digital and economic divide between urban and rural areas that might have occurred in the absence of the respective state aid program. Such aspects need to be investigated as part of future research - in working towards well-founded conclusions on effective and efficient ways to bridge the digital and economic divide. 


\section{Annex}

Table A.1: Description of variables and sources

\begin{tabular}{|c|c|c|}
\hline Variable & Description & Source \\
\hline \multicolumn{3}{|c|}{ Outcome variables stage 1} \\
\hline HH_XMB & $\begin{array}{l}\text { Share of households with at least XMB fixed-line broadband } \\
\text { connections. X can take the values } 2,6 \text { and } 16 \text {, municipality } \\
\text { level }(2010-2014)\end{array}$ & $\begin{array}{l}\text { Breitbandatlas/ } \\
\text { TÜV Rheinland }\end{array}$ \\
\hline \multicolumn{3}{|c|}{ Outcome variables stage 2} \\
\hline EMPL_RES & $\begin{array}{l}\text { Number of employees with social insurance, municipality level } \\
\text { at place of residence per } 100 \text { residents }(2010-2014)\end{array}$ & GENESIS \\
\hline EMPL_WORK & $\begin{array}{l}\text { Number of employees with social insurance, municipality level } \\
\text { at place of work per } 100 \text { residents }(2010-2014)\end{array}$ & GENESIS \\
\hline EMPL_SELF & $\begin{array}{l}\text { Number of self-employed workers and freelancers, municipality } \\
\text { level per } 100 \text { residents }(2010-2014)\end{array}$ & ACXIOM \\
\hline WAGE & $\begin{array}{l}\text { Annual gross wage in } € \text { per employee in a municipality (2010- } \\
2014)\end{array}$ & GENESIS \\
\hline \multicolumn{3}{|c|}{ Treatment variable } \\
\hline$\overline{D_{1}}$ & $\begin{array}{l}\text { Dummy on whether a municipality received state aid between } \\
2010 \text { and } 2011 \text {, municipality level }\end{array}$ & $\begin{array}{l}\text { Schnelles Internet } \\
\text { für Bayern }\end{array}$ \\
\hline \multicolumn{3}{|c|}{ Control variables } \\
\hline $\mathrm{HH}$ & Number of households, municipality level (2010) & Micro Census 2011 \\
\hline GR_RENT & Annual growth in rents, municipality level (2007-2009) & $\begin{array}{l}\text { IDN Immo } \\
\text { Daten GmbH }\end{array}$ \\
\hline GR_1MB & $\begin{array}{l}\text { Average yearly growth rate in the share of households with } \\
\text { access to } 1 \mathrm{MB} \text {, municipality level }(2007-2009)\end{array}$ & $\begin{array}{l}\text { Breitbandatlas/ } \\
\text { TÜV Rheinland }\end{array}$ \\
\hline TYPE_X & $\begin{array}{l}\text { Municipality type, indicator of how rural a municipality is } \\
(2010)\end{array}$ & INKAR \\
\hline FEMALE & Share of female inhabitants, municipality level (2010-2014) & GENESIS \\
\hline WORKING_AGE & $\begin{array}{l}\text { Share of people in working age, i.e., } 18 \text { to } 65 \text { years, } \\
\text { municipality level (2010-2014) }\end{array}$ & INKAR \\
\hline POP_DENS & $\begin{array}{l}\text { Population density per square kilometer, municipality level } \\
\left.(2010-2013)^{* *}\right)\end{array}$ & GENESIS \\
\hline GVA_SEC & $\begin{array}{l}\text { Share of gross value added in secondary sector, county level } \\
\left.(2010-2013)^{* *}\right)\end{array}$ & INKAR \\
\hline GVA_TER & $\begin{array}{l}\text { Share of gross value added in tertiary sector, county level } \\
\left.(2010-2013)^{* *}\right)\end{array}$ & INKAR \\
\hline FIRM_MED & $\begin{array}{l}\text { Share of firms with } 50 \text { to } 250 \text { employees, county level (2010- } \\
2013)^{* *)}\end{array}$ & INKAR \\
\hline FIRM_BIG & $\begin{array}{l}\text { Share of firms with more than } 250 \text { employees, county level } \\
\left.(2010-2013)^{* *}\right)\end{array}$ & INKAR \\
\hline CSU & Share of the CSU party in the municipal election (2008-2014) & GENESIS \\
\hline SPD & Share of the SPD party in the municipal election (2008-2014) & GENESIS \\
\hline ACC_MOTOR & $\begin{array}{l}\text { Average journey time (car) in minutes to the next motorway, } \\
\left.\text { municipality level }(2010,2012-2014)^{*}\right)\end{array}$ & INKAR \\
\hline ACC_CITIES & $\begin{array}{l}\text { Average journey time (car) in minutes to the next regional } \\
\left.\text { metropolitan area, municipality level }(2010,2012-2014)^{*}\right)\end{array}$ & INKAR \\
\hline EDUC & $\begin{array}{l}\text { Percentage share of school leavers with a higher education entry } \\
\text { qualification in the total number of school leavers, county level } \\
\left.(2010-2013)^{* *}\right)\end{array}$ & INKAR \\
\hline
\end{tabular}

Notes: ${ }^{*}$ Missing values for 2011 were calculated using linear interpolation. ${ }^{* *}$ In case control variables were only available up to the year 2013, we have extrapolated them to the year 2014 . 
Table A.2: Summary statistics

\begin{tabular}{|c|c|c|c|c|c|}
\hline & \# Obs. & Mean & Std. Dev. & Min. & Max. \\
\hline HH_2MB & 9,425 & 80.351 & 26.727 & 0.000 & 100.000 \\
\hline HH_6MB & 9,425 & 66.734 & 32.788 & 0.000 & 100.000 \\
\hline $\mathrm{HH} 16 \mathrm{MB}$ & 9,425 & 50.150 & 34.103 & 0.000 & 100.000 \\
\hline EMPL_RES & 9,425 & 38.234 & 3.517 & 21.463 & 52.522 \\
\hline EMPL_WORK & 9,425 & 22.759 & 18.457 & 0.930 & 200.573 \\
\hline EMPL_SELF & 9,425 & 3.369 & 1.147 & 0.558 & 8.150 \\
\hline WAGE & 9,425 & 25520.433 & 4318.374 & 13662.086 & 83865.617 \\
\hline $\mathrm{D}_{1}$ & 9,425 & 0.599 & 0.490 & 0.000 & 1.000 \\
\hline EDUCC & 9,425 & 25.965 & 9.796 & 8.900 & 70.300 \\
\hline WORKING_AGE & 9,425 & 63.289 & 2.135 & 52.800 & 70.700 \\
\hline GR_RENT & 9,425 & 2.288 & 2.803 & 0.000 & 5.885 \\
\hline GR_1MB & 9,425 & 1.363 & 5.465 & -42.855 & 50.000 \\
\hline TYPEE_1 & 9,425 & 0.003 & 0.056 & 0.000 & 1.000 \\
\hline TYPE_2 & 9,425 & 0.029 & 0.168 & 0.000 & 1.000 \\
\hline TYPE_3 & 9,425 & 0.077 & 0.266 & 0.000 & 1.000 \\
\hline TYPE_4 & 9,425 & 0.266 & 0.442 & 0.000 & 1.000 \\
\hline TYPE_5 & 9,425 & 0.624 & 0.484 & 0.000 & 1.000 \\
\hline $\mathrm{HH}$ & 9,425 & 2.760 & 18.552 & 0.088 & 732.793 \\
\hline FEMALE & 9,425 & 50.111 & 1.418 & 36.100 & 56.700 \\
\hline POP_DENS & 9,425 & 189.626 & 292.660 & 6.000 & 4531.200 \\
\hline FIRM_MED & 9,425 & 15.325 & 3.754 & 8.200 & 40.200 \\
\hline FIRM_BIG & 9,425 & 2.570 & 0.941 & 0.480 & 7.470 \\
\hline GVA_SEC & 9,425 & 37.908 & 9.601 & 12.800 & 71.700 \\
\hline GVA_TER & 9,425 & 60.227 & 9.710 & 26.800 & 86.500 \\
\hline $\mathrm{CSU}$ & 9,425 & 0.246 & 0.205 & 0.000 & 1.000 \\
\hline SPD & 9,425 & 0.109 & 0.130 & 0.000 & 0.663 \\
\hline ACC_MOTOR & 9,425 & 14.662 & 10.790 & 0.000 & 69.000 \\
\hline ACC_CITIES & 9,425 & 29.029 & 14.172 & 0.000 & 82.300 \\
\hline
\end{tabular}


Table A.3: Descriptive statistics of the used samples / sample means before matching

\begin{tabular}{|c|c|c|c|c|c|c|}
\hline & \multicolumn{2}{|c|}{$\begin{array}{l}\text { Control group } \\
\qquad \mathrm{N}=756 \\
\end{array}$} & \multicolumn{2}{|c|}{$\begin{array}{c}\text { Aid-receiving } \\
\text { municipalities } \\
\mathrm{N}=1,129 \\
\end{array}$} & \multicolumn{2}{|c|}{$\begin{array}{c}\text { Results of } t \text {-test on mean } \\
\text { differences }\end{array}$} \\
\hline & mean & S.D. & mean & S.D. & Diff & $t$-value \\
\hline \multicolumn{7}{|l|}{ Covariates } \\
\hline HH_2MB_2010 & 79.96 & 26.54 & 58.94 & 33.02 & $* * *$ & $(15.26)$ \\
\hline HH_6MB_2010 & 64.60 & 31.80 & 39.75 & 33.68 & $* * *$ & $(16.23)$ \\
\hline HH_16MB_2010 & 39.25 & 32.89 & 24.62 & 28.83 & $* * *$ & $(9.94)$ \\
\hline GR_RENT & 0.05 & 0.02 & 0.05 & 0.02 & & $(-1.29)$ \\
\hline GR_1MB & 5.43 & 5.65 & 5.27 & 4.91 & & $(0.66)$ \\
\hline $\mathrm{HH}^{-}$ & 3.44 & 27.47 & 2.31 & 8.34 & & (1.10) \\
\hline WORKING_AGE & 62.52 & 2.21 & 62.93 & 1.91 & $* * *$ & $(-4.22)$ \\
\hline FEMALE & 50.35 & 1.49 & 49.97 & 1.53 & $* * *$ & $(5.32)$ \\
\hline POP_DENS & 239.50 & 396.52 & 157.27 & 186.10 & $* * *$ & $(5.32)$ \\
\hline TYPE _1 & 0.01 & 0.07 & 0.00 & 0.04 & & $(1.20)$ \\
\hline TYPE_2 & 0.03 & 0.17 & 0.03 & 0.17 & & $(0.26)$ \\
\hline TYPE_3 & 0.07 & 0.26 & 0.08 & 0.27 & & $(-0.56)$ \\
\hline TYPE_4 & 0.23 & 0.42 & 0.29 & 0.46 & $* * *$ & $(-3.29)$ \\
\hline TYPE_5 & 0.67 & 0.47 & 0.60 & 0.49 & $* * *$ & $(3.03)$ \\
\hline FIRM_MED & 14.70 & 3.81 & 14.89 & 3.62 & & $(-1.11)$ \\
\hline FIRM_BIG & 2.38 & 0.89 & 2.43 & 0.91 & & $(-1.25)$ \\
\hline GVA_SEC & 36.42 & 10.34 & 37.74 & 9.36 & $* * *$ & $(-2.83)$ \\
\hline GVA_TER & 61.80 & 10.47 & 60.48 & 9.43 & $* * *$ & $(2.79)$ \\
\hline $\mathrm{CSU}$ & 0.26 & 0.20 & 0.24 & 0.21 & $* * *$ & $(2.83)$ \\
\hline SPD & 0.13 & 0.14 & 0.10 & 0.12 & $* * *$ & $(4.35)$ \\
\hline ACC_MOTOR & 12.98 & 9.21 & 15.84 & 11.55 & $* * *$ & $(-5.95)$ \\
\hline ACC_CITIES & 28.77 & 14.65 & 31.97 & 14.92 & $* * *$ & $(-4.62)$ \\
\hline \multicolumn{7}{|l|}{ Outcome variables } \\
\hline HH_2MB_2012 & 82.58 & 24.36 & 80.55 & 26.04 & $*$ & $(1.72)$ \\
\hline HH_2MB_2013 & 86.07 & 21.64 & 87.82 & 19.97 & $*$ & $(-1.77)$ \\
\hline HH_2MB_2014 & 87.54 & 20.51 & 92.09 & 14.44 & $* * *$ & $(-5.28)$ \\
\hline HH_6MB_2012 & 67.63 & 30.67 & 68.23 & 31.67 & & $(-0.41)$ \\
\hline HH_6MB_2013 & 72.20 & 29.39 & 77.82 & 27.17 & $* * *$ & $(-4.19)$ \\
\hline HH_6MB_2014 & 74.58 & 28.70 & 84.76 & 20.93 & $* * *$ & $(-8.38)$ \\
\hline HH_16MB_2012 & 50.90 & 30.80 & 57.09 & 32.25 & $* * *$ & $(-4.20)$ \\
\hline HH_16MB_2013 & 50.98 & 32.51 & 61.70 & 30.76 & $* * *$ & $(-7.17)$ \\
\hline HH_16MB_2014 & 55.91 & 32.56 & 72.60 & 27.05 & $* * *$ & $(-11.66)$ \\
\hline \# Obs. & 756 & & 1129 & & 1885 & \\
\hline
\end{tabular}


Table A.4: Probit regression results

\begin{tabular}{|c|c|c|}
\hline $\begin{array}{l}\text { Dep. var } \\
\left(\operatorname{Pr}\left(D_{l}=1\right)\right)\end{array}$ & Coefficient & Standard error \\
\hline HH_2MB_2010 & -0.0034 & $(-1.68)$ \\
\hline HH_6MB_2010 & $-0.0163^{* * *}$ & $(-6.98)$ \\
\hline HH_16MB_2010 & $0.0054^{* *}$ & (3.08) \\
\hline GR_RENT & 0.7224 & $(0.64)$ \\
\hline GR_1MB & -0.0152 & $(-1.90)$ \\
\hline $\mathrm{HH}$ & 0.0025 & $(0.96)$ \\
\hline WORKING_AGE & $0.0686^{* * *}$ & (4.08) \\
\hline FEMALE & -0.0221 & $(-0.91)$ \\
\hline POP_DENS & $-0.0008^{* * *}$ & $(-4.13)$ \\
\hline TYPE _1 & 0.8892 & (1.14) \\
\hline TYPE_2 & $1.1595^{* * *}$ & (5.26) \\
\hline TYPE_3 & $0.9295^{* * *}$ & (6.79) \\
\hline TYPE_4 & $0.6179^{* * *}$ & (7.81) \\
\hline TYPE _5 & 0.0000 & (.) \\
\hline FIRM_MED & 0.0015 & $(0.12)$ \\
\hline FIRM_BIG & 0.0114 & $(0.21)$ \\
\hline GVA_SEC & $0.1517^{* *}$ & (3.16) \\
\hline GVA_TER & $0.1481^{* *}$ & (3.08) \\
\hline CSU & 0.0558 & $(0.32)$ \\
\hline SPD & -0.2006 & $(-0.68)$ \\
\hline ACC_MOTOR & $0.0110^{* *}$ & (2.89) \\
\hline ACC_CITIES & 0.0028 & (1.02) \\
\hline Constant & $-17.1135^{* * *}$ & $(-3.34)$ \\
\hline $\begin{array}{l}\text { \# Obs. } \\
\text { Pseudo } R^{2} \\
p \text {-value }\left(\text { Prob }>c h i^{2}\right)\end{array}$ & \multicolumn{2}{|c|}{$\begin{array}{l}0.158 \\
0.000 \\
\end{array}$} \\
\hline
\end{tabular}


Table A.5: Static and dynamic DiD models with controls based on matched and weighted sample

\begin{tabular}{|c|c|c|c|c|c|c|}
\hline Dep. var.: & $\begin{array}{c}(1) \\
\text { HH_2MB } \\
\end{array}$ & $\begin{array}{c}(2) \\
\text { HH_2MB } \\
\end{array}$ & $\begin{array}{c}(3) \\
\text { HH_6MB } \\
\end{array}$ & $\begin{array}{c}(4) \\
\text { HH_6MB } \\
\end{array}$ & $\begin{array}{c}(5) \\
\text { HH_16MB } \\
\end{array}$ & $\begin{array}{c}(6) \\
\text { HH_16MB } \\
\end{array}$ \\
\hline ATE & $\begin{array}{c}\mathbf{1 6 . 7 5 6 3}^{\text {****** }} \\
(22.04)\end{array}$ & & $\begin{array}{c}\text { 23.2355 }^{\text {***** }} \\
(25.71)\end{array}$ & & $\begin{array}{c}\mathbf{2 0 . 2 1 0 3}^{\text {**** }} \\
(19.88)\end{array}$ & \\
\hline ATE 1 year post & & $\begin{array}{c}\text { 13.6111 }^{* * * *} \\
(18.56)\end{array}$ & & $\begin{array}{c}\mathbf{1 8 . 7 4 6 9}^{\text {***** }} \\
(21.36)\end{array}$ & & $\begin{array}{c}\mathbf{1 5 . 4 3 0 8}^{* * * *} \\
(14.48)\end{array}$ \\
\hline ATE 2 year post & & $\begin{array}{c}\mathbf{1 7 . 2 0 4 7}^{\text {**** }} \\
(20.79)\end{array}$ & & $\begin{array}{c}\mathbf{2 3 . 5 2 2 7}^{* * * *} \\
(23.33)\end{array}$ & & $\begin{array}{c}\text { 19.9361 }^{* * * * *} \\
(17.25)\end{array}$ \\
\hline ATE 3 year post & & $\begin{array}{c}\text { 19.3537 }^{\text {**** }} \\
(21.05)\end{array}$ & & $\begin{array}{c}\mathbf{2 7 . 2 1 3 8}^{* * * *} \\
(24.16)\end{array}$ & & $\begin{array}{c}\mathbf{2 5 . 2 4 6 7}^{* * * *} \\
(19.24)\end{array}$ \\
\hline WORKING_AGE & $\begin{array}{c}4.3977^{* * *} \\
(7.24)\end{array}$ & $\begin{array}{c}3.7082^{* * * *} \\
(5.81)\end{array}$ & $\begin{array}{c}4.6779^{* * *} \\
(6.72)\end{array}$ & $\begin{array}{c}3.3789^{* * * *} \\
(4.71)\end{array}$ & $\begin{array}{c}3.4330^{* * * *} \\
(5.05)\end{array}$ & $\begin{array}{c}2.7544^{* * * *} \\
(3.91)\end{array}$ \\
\hline FEMALE & $\begin{array}{c}0.5471 \\
(0.77)\end{array}$ & $\begin{array}{c}0.8411 \\
(1.18)\end{array}$ & $\begin{array}{c}0.6550 \\
(0.83)\end{array}$ & $\begin{array}{l}1.1871 \\
(1.50)\end{array}$ & $\begin{array}{l}0.6518 \\
(0.89)\end{array}$ & $\begin{array}{l}1.1986 \\
(1.63)\end{array}$ \\
\hline POP_DENS & $\begin{array}{c}-0.0799^{* *} \\
(-2.08)\end{array}$ & $\begin{array}{c}-0.0883^{* * *} \\
(-2.16)\end{array}$ & $\begin{array}{c}-0.0914^{* *} \\
(-1.98)\end{array}$ & $\begin{array}{c}-0.1100^{* * *} \\
(-2.16)\end{array}$ & $\begin{array}{c}-0.0458 \\
(-1.07)\end{array}$ & $\begin{array}{l}-0.0475 \\
(-1.09)\end{array}$ \\
\hline FIRM_MED & $\begin{array}{c}2.3316^{* * * *} \\
(5.46)\end{array}$ & $\begin{array}{c}1.6017^{* * * *} \\
(3.32)\end{array}$ & $\begin{array}{c}3.0448^{* * * *} \\
(6.00)\end{array}$ & $\begin{array}{c}1.6284^{* * * *} \\
(2.89)\end{array}$ & $\begin{array}{c}2.4527^{* * * *} \\
(4.92)\end{array}$ & $\begin{array}{c}1.8246^{* * *} \\
(3.30)\end{array}$ \\
\hline FIRM_BIG & $\begin{array}{c}6.9912^{* * *} \\
(4.13)\end{array}$ & $\begin{array}{c}5.4900^{* * * *} \\
(3.06)\end{array}$ & $\begin{array}{c}8.9559^{* * *} \\
(4.46)\end{array}$ & $\begin{array}{c}5.9642^{* * * *} \\
(2.82)\end{array}$ & $\begin{array}{c}8.0731^{* * *} \\
(3.97)\end{array}$ & $\begin{array}{c}6.8768^{* * * *} \\
(3.19)\end{array}$ \\
\hline L.GVA_SEC & $\begin{array}{c}-4.2449^{* * * *} \\
(-2.87)\end{array}$ & $\begin{array}{c}-3.0847^{* * *} \\
(-2.00)\end{array}$ & $\begin{array}{c}-7.5940^{* * * *} \\
(-4.35)\end{array}$ & $\begin{array}{c}-5.1696^{* * * *} \\
(-2.84)\end{array}$ & $\begin{array}{c}-5.5065^{* * * *} \\
(-3.14)\end{array}$ & $\begin{array}{c}-5.7733^{* * * *} \\
(-3.17)\end{array}$ \\
\hline L.GVA_TER & $\begin{array}{c}-5.0014^{* * * *} \\
(-3.35)\end{array}$ & $\begin{array}{c}-3.8309^{* * *} \\
(-2.47)\end{array}$ & $\begin{array}{c}-8.6717^{* * * * *} \\
(-4.92)\end{array}$ & $\begin{array}{c}-6.2355^{* * * *} \\
(-3.39)\end{array}$ & $\begin{array}{c}-6.8736^{* * * *} \\
(-3.87)\end{array}$ & $\begin{array}{c}-7.0870^{* * * *} \\
(-3.84)\end{array}$ \\
\hline CSU & $\begin{array}{l}-1.9837 \\
(-0.35)\end{array}$ & $\begin{array}{c}-0.6329 \\
(-0.11)\end{array}$ & $\begin{array}{l}-6.7633 \\
(-1.05)\end{array}$ & $\begin{array}{l}-4.4937 \\
(-0.71)\end{array}$ & $\begin{array}{l}-8.8715 \\
(-1.36)\end{array}$ & $\begin{array}{l}-6.0305 \\
(-0.95)\end{array}$ \\
\hline SPD & $\begin{array}{l}8.2660 \\
(1.27)\end{array}$ & $\begin{array}{c}15.2402^{* *} \\
(2.25)\end{array}$ & $\begin{array}{l}0.1855 \\
(0.02)\end{array}$ & $\begin{array}{c}12.5843 \\
(1.40)\end{array}$ & $\begin{array}{c}0.3622 \\
(0.03)\end{array}$ & $\begin{array}{c}16.0559 \\
(1.52)\end{array}$ \\
\hline ACC_MOTOR & $\begin{array}{c}-0.1248 \\
(-0.41)\end{array}$ & $\begin{array}{l}-0.0507 \\
(-0.18)\end{array}$ & $\begin{array}{l}-0.2615 \\
(-0.54)\end{array}$ & $\begin{array}{c}-0.0983 \\
(-0.21)\end{array}$ & $\begin{array}{l}0.0641 \\
(0.13)\end{array}$ & $\begin{array}{l}0.0918 \\
(0.19)\end{array}$ \\
\hline ACC_CITIES & $\begin{array}{c}-0.0339 \\
(-0.86)\end{array}$ & $\begin{array}{l}0.0180 \\
(0.43)\end{array}$ & $\begin{array}{l}-0.0746 \\
(-1.32)\end{array}$ & $\begin{array}{l}0.0283 \\
(0.46)\end{array}$ & $\begin{array}{c}-0.0594 \\
(-0.97)\end{array}$ & $\begin{array}{c}-0.0174 \\
(-0.26)\end{array}$ \\
\hline $\begin{array}{l}\text { Post treatment } \\
\text { period }\end{array}$ & $\begin{array}{c}-3.5423^{* * * *} \\
(-6.44)\end{array}$ & & $\begin{array}{c}-4.1776^{* * *} \\
(-6.48)\end{array}$ & & $\begin{array}{c}1.8005^{* * *} \\
(2.26)\end{array}$ & \\
\hline YEAR 2012 & & $\begin{array}{c}-1.6398^{* * * *} \\
(-3.88)\end{array}$ & & $\begin{array}{c}-1.7626^{* * * *} \\
(-3.83)\end{array}$ & & $\begin{array}{l}5.0874^{* * * *} \\
(6.78)\end{array}$ \\
\hline YEAR 2013 & & $\begin{array}{c}-3.0763^{* * * *} \\
(-3.27)\end{array}$ & & $\begin{array}{c}-2.3610^{* *} \\
(-2.12)\end{array}$ & & $\begin{array}{c}-0.3720 \\
(-0.31)\end{array}$ \\
\hline YEAR 2014 & & $\begin{array}{r}-1.4917 \\
(-1.50)\end{array}$ & & $\begin{array}{l}0.1637 \\
(0.14)\end{array}$ & & $\begin{array}{c}4.5042^{* * * *} \\
(3.42)\end{array}$ \\
\hline Constant & $\begin{array}{c}194.3866 \\
(1.14)\end{array}$ & $\begin{array}{c}120.6963 \\
(0.70) \\
\end{array}$ & $\begin{array}{c}495.0074^{* *} \\
(2.53)\end{array}$ & $\begin{array}{c}335.4202^{*} \\
(1.69)\end{array}$ & $\begin{array}{c}367.5307^{*} \\
(1.89)\end{array}$ & $\begin{array}{c}414.2523^{* *} \\
(2.10)\end{array}$ \\
\hline \# Obs. & 8,120 & 8,120 & 8,120 & 8,120 & 8,120 & 8,120 \\
\hline $\mathrm{R}^{2}$ within & 0.2673 & 0.3370 & 0.2949 & 0.3957 & 0.3151 & 0.4170 \\
\hline F-Test & 88.44 & 74.24 & 121.90 & 102.86 & 150.81 & 130.06 \\
\hline
\end{tabular}


Table A.6: Immediate and long-term treatment effects for PSM

\begin{tabular}{|c|c|c|c|c|c|c|}
\hline \multirow[b]{2}{*}{ Dep. var.: } & \multicolumn{3}{|c|}{$(2 \mathrm{NB})$} & \multicolumn{3}{|c|}{$(3 \mathrm{NB})$} \\
\hline & HH_2MB & HH_6MB & HH_16MB & HH_2MB & HH_6MB & HH_16MB \\
\hline ATE 2012 & $\begin{array}{c}12.19^{* * *} \\
(9.58)\end{array}$ & $\begin{array}{l}18.29^{* * *} \\
(14.65)\end{array}$ & $\begin{array}{l}18.16^{* * *} \\
(14.37)\end{array}$ & $\begin{array}{l}12.56^{* * *} \\
(11.35)\end{array}$ & $\begin{array}{l}18.30^{* * *} \\
(16.37)\end{array}$ & $\begin{array}{l}18.26^{* * *} \\
(16.01)\end{array}$ \\
\hline ATT 2012 & $\begin{array}{c}15.91^{* * *} \\
(8.29)\end{array}$ & $\begin{array}{l}22.60^{* * *} \\
(12.73)\end{array}$ & $\begin{array}{c}21.77^{* * *} \\
(12.88)\end{array}$ & $\begin{array}{l}16.56^{* * *} \\
(10.14)\end{array}$ & $\begin{array}{l}22.70^{* * *} \\
(14.68)\end{array}$ & $\begin{array}{c}21.79^{* * *} \\
(14.73)\end{array}$ \\
\hline ATE 2013 & $\begin{array}{l}12.96^{* * *} \\
(11.43)\end{array}$ & $\begin{array}{l}21.08^{* * *} \\
(17.02)\end{array}$ & $\begin{array}{c}20.07^{* * * *} \\
(15.38)\end{array}$ & $\begin{array}{c}13.47^{* * *} \\
(13.30)\end{array}$ & $\begin{array}{l}21.45^{* * *} \\
(19.42)\end{array}$ & $\begin{array}{c}20.52^{* * *} \\
(17.55)\end{array}$ \\
\hline ATT 2013 & $\begin{array}{c}16.92^{* * *} \\
(9.88)\end{array}$ & $\begin{array}{l}26.13^{* * *} \\
(14.76)\end{array}$ & $\begin{array}{c}23.37^{* * * *} \\
(13.26)\end{array}$ & $\begin{array}{l}17.58^{* * *} \\
(11.74)\end{array}$ & $\begin{array}{l}26.50^{* * *} \\
(17.25)\end{array}$ & $\begin{array}{l}23.76^{\text {**** }} \\
(15.52)\end{array}$ \\
\hline ATE 2014 & $\begin{array}{l}13.24^{* * *} \\
(13.76)\end{array}$ & $\begin{array}{l}22.37^{* * *} \\
(19.94)\end{array}$ & $\begin{array}{l}23.54^{* * *} \\
(17.81)\end{array}$ & $\begin{array}{l}13.86^{* * *} \\
(13.76)\end{array}$ & $\begin{array}{c}22.82^{* * *} \\
(19.76)\end{array}$ & $\begin{array}{l}23.86^{\text {**** }} \\
(17.94)\end{array}$ \\
\hline ATT 2014 & $\begin{array}{l}17.11^{* * *} \\
(12.04)\end{array}$ & $\begin{array}{l}27.70^{* * *} \\
(18.07)\end{array}$ & $\begin{array}{c}27.37^{* * *} \\
(16.44)\end{array}$ & $\begin{array}{l}18.01^{* * *} \\
(12.02)\end{array}$ & $\begin{array}{c}28.28^{* * *} \\
(17.62)\end{array}$ & $\begin{array}{c}27.85^{\text {**** }} \\
(16.31)\end{array}$ \\
\hline \# Obs. & 1,833 & 1,833 & 1,833 & 1,833 & 1,833 & 1,833 \\
\hline
\end{tabular}


Table A.7: Second stage full IV/2SLS model with matched and weighted sample

\begin{tabular}{|c|c|c|c|}
\hline Dep. var.: & $\begin{array}{c}\text { (1) } \\
\text { EMPL_RES }\end{array}$ & $\begin{array}{c}(2) \\
\text { EMPL_RES }\end{array}$ & $\begin{array}{c}\text { (3) } \\
\text { EMPL_RES }\end{array}$ \\
\hline HH_2MB & $\begin{array}{c}\mathbf{0 . 0 0 8 6}^{* * * *} \\
(3.15)\end{array}$ & & \\
\hline HH_6MB & & $\begin{array}{c}0.0062^{* * *} \\
(3.15)\end{array}$ & \\
\hline HH_16MB & & & $\begin{array}{c}\mathbf{0 . 0 0 7 1}^{* * * *} \\
(\mathbf{3 . 1 3})\end{array}$ \\
\hline WORKING_AGE & $\begin{array}{c}-0.0670^{* * *} \\
(-2.09)\end{array}$ & $\begin{array}{c}-0.0569^{*} \\
(-1.82)\end{array}$ & $\begin{array}{c}-0.0538^{*} \\
(-1.73)\end{array}$ \\
\hline FEMALE & $\begin{array}{l}0.1012^{* *} \\
(2.20)\end{array}$ & $\begin{array}{c}0.1007^{* *} \\
(2.17)\end{array}$ & $\begin{array}{l}0.1003^{* *} \\
(2.15)\end{array}$ \\
\hline POP_DENS & $\begin{array}{c}-0.0226^{* * *} \\
(-3.40)\end{array}$ & $\begin{array}{c}-0.0227^{* * *} \\
(-3.40)\end{array}$ & $\begin{array}{c}-0.0231^{* * * *} \\
(-3.44)\end{array}$ \\
\hline FIRM_MED & $\begin{array}{c}-0.0245 \\
(-1.01)\end{array}$ & $\begin{array}{c}-0.0223 \\
(-0.92)\end{array}$ & $\begin{array}{l}-0.0217 \\
(-0.89)\end{array}$ \\
\hline FIRM_BIG & $\begin{array}{c}0.1330^{*} \\
(1.82)\end{array}$ & $\begin{array}{c}0.1394^{*} \\
(1.92)\end{array}$ & $\begin{array}{c}0.1376^{*} \\
(1.88)\end{array}$ \\
\hline L.GVA_SEC & $\begin{array}{c}0.1699^{* *} \\
(2.01)\end{array}$ & $\begin{array}{c}0.1782^{* * *} \\
(2.11)\end{array}$ & $\begin{array}{l}0.1805^{* *} \\
(2.13)\end{array}$ \\
\hline L.GVA_TER & $\begin{array}{c}0.1690^{* *} \\
(1.97)\end{array}$ & $\begin{array}{l}0.1781^{* *} \\
(2.08)\end{array}$ & $\begin{array}{c}0.1815^{* *} \\
(2.11)\end{array}$ \\
\hline CSU & $\begin{array}{c}0.3580 \\
(0.75)\end{array}$ & $\begin{array}{c}0.3813 \\
(0.81)\end{array}$ & $\begin{array}{c}0.3967 \\
(0.84)\end{array}$ \\
\hline SPD & $\begin{array}{c}-0.4596 \\
(-0.97)\end{array}$ & $\begin{array}{c}-0.4095 \\
(-0.85)\end{array}$ & $\begin{array}{c}-0.4480 \\
(-0.92)\end{array}$ \\
\hline ACC_MOTOR & $\begin{array}{c}-0.0032 \\
(-0.24)\end{array}$ & $\begin{array}{c}-0.0029 \\
(-0.23)\end{array}$ & $\begin{array}{c}-0.0045 \\
(-0.35)\end{array}$ \\
\hline ACC_CITIES & $\begin{array}{c}0.0041^{* *} \\
(1.99)\end{array}$ & $\begin{array}{c}0.0042^{* *} \\
(2.01)\end{array}$ & $\begin{array}{c}0.0043^{* *} \\
(2.08)\end{array}$ \\
\hline EDUC & $\begin{array}{c}-0.0014 \\
(-0.25) \\
\end{array}$ & $\begin{array}{c}-0.0011 \\
(-0.20) \\
\end{array}$ & $\begin{array}{c}-0.0010 \\
(-0.17) \\
\end{array}$ \\
\hline $\begin{array}{l}\text { \# Obs. } \\
R^{2}\end{array}$ & $\begin{array}{l}8,120 \\
0.702\end{array}$ & $\begin{array}{l}8,120 \\
0702\end{array}$ & $\begin{array}{l}8,120 \\
0,697\end{array}$ \\
\hline$F$ & 634.48 & 634.27 & 626.20 \\
\hline$F$-Test of excl. instr. & 755.81 & 1041.29 & 633.63 \\
\hline$D W H$ & 0.0103 & 0.0047 & 0.0011 \\
\hline
\end{tabular}


Table A.8: Second stage OLS estimates for self-employment and gross wages

\begin{tabular}{|c|c|c|c|c|c|c|}
\hline $\begin{array}{l}\text { Dep. var.: } \\
\text { Sample: }\end{array}$ & $\begin{array}{c}(1) \\
\text { SELF } \\
\text { Matched \& } \\
\text { Weighted }\end{array}$ & $\begin{array}{c}(2) \\
\text { SELF } \\
\text { Matched \& } \\
\text { Weighted }\end{array}$ & $\begin{array}{c}(3) \\
\text { SELF } \\
\text { Matched \& } \\
\text { Weighted }\end{array}$ & $\begin{array}{c}(4) \\
\text { WAGE } \\
\text { Matched \& } \\
\text { Weighted }\end{array}$ & $\begin{array}{c}(5) \\
\text { WAGE } \\
\text { Matched \& } \\
\text { Weighted }\end{array}$ & $\begin{array}{c}(6) \\
\text { WAGE } \\
\text { Matched \& } \\
\text { Weighted }\end{array}$ \\
\hline HH_2MB & $\begin{array}{c}0.0003^{* *} \\
(2.22)\end{array}$ & & & $\begin{array}{c}1.3524^{* *} \\
(2.52)\end{array}$ & & \\
\hline HH_6MB & & $\begin{array}{c}0.0002^{*} \\
(1.91)\end{array}$ & & & $\begin{array}{c}1.0131^{* *} \\
(2.33)\end{array}$ & \\
\hline HH_16MB & & & $\begin{array}{c}0.0001 \\
(0.90)\end{array}$ & & & $\begin{array}{c}0.8739^{* *} \\
(2.16)\end{array}$ \\
\hline WORKING_AGE & $\begin{array}{c}-0.0088^{*} \\
(-1.88)\end{array}$ & $\begin{array}{c}-0.0085^{*} \\
(-1.81)\end{array}$ & $\begin{array}{c}-0.0081^{*} \\
(-1.73)\end{array}$ & $\begin{array}{c}-36.1891^{*} \\
(-1.78)\end{array}$ & $\begin{array}{c}-34.6957^{*} \\
(-1.70)\end{array}$ & $\begin{array}{c}-33.5371 \\
(-1.65)\end{array}$ \\
\hline FEMALE & $\begin{array}{c}0.0126^{* *} \\
(2.57)\end{array}$ & $\begin{array}{c}0.0126^{* *} \\
(2.57)\end{array}$ & $\begin{array}{c}0.0127^{\text {**** }} \\
(2.59)\end{array}$ & $\begin{array}{c}35.0609 \\
(1.31)\end{array}$ & $\begin{array}{c}34.9465 \\
(1.31)\end{array}$ & $\begin{array}{c}35.1765 \\
(1.32)\end{array}$ \\
\hline POP_DENS & $\begin{array}{c}-0.0033^{* * *} \\
(-3.37)\end{array}$ & $\begin{array}{c}-0.0033^{* * *} \\
(-3.37)\end{array}$ & $\begin{array}{c}-0.0033^{* * *} \\
(-3.37)\end{array}$ & $\begin{array}{l}1.5518 \\
(0.58)\end{array}$ & $\begin{array}{c}1.5495 \\
(0.58)\end{array}$ & $\begin{array}{l}1.4703 \\
(0.56)\end{array}$ \\
\hline FIRM_MED & $\begin{array}{c}0.0075^{*} \\
(1.72)\end{array}$ & $\begin{array}{c}0.0075^{*} \\
(1.73)\end{array}$ & $\begin{array}{c}0.0074^{*} \\
(1.71)\end{array}$ & $\begin{array}{l}1.8661 \\
(0.14)\end{array}$ & $\begin{array}{c}2.2388 \\
(0.17)\end{array}$ & $\begin{array}{c}2.0960 \\
(0.16)\end{array}$ \\
\hline FIRM_BIG & $\begin{array}{c}0.0229^{* *} \\
(2.01)\end{array}$ & $\begin{array}{c}0.0231^{* *} \\
(2.03)\end{array}$ & $\begin{array}{c}0.0230^{* *} \\
(2.02)\end{array}$ & $\begin{array}{c}-24.9602 \\
(-0.50)\end{array}$ & $\begin{array}{c}-23.9392 \\
(-0.48)\end{array}$ & $\begin{array}{c}-24.2326 \\
(-0.49)\end{array}$ \\
\hline L.GVA_SEC & $\begin{array}{c}0.0238^{*} \\
(1.94)\end{array}$ & $\begin{array}{c}0.0240^{*} \\
(1.96)\end{array}$ & $\begin{array}{c}0.0240^{*} \\
(1.96)\end{array}$ & $\begin{array}{c}-133.3653^{* * *} \\
(-2.70)\end{array}$ & $\begin{array}{c}-132.0566^{* * *} \\
(-2.68)\end{array}$ & $\begin{array}{c}-131.8256^{* * *} \\
(-2.67)\end{array}$ \\
\hline L.GVA_TER & $\begin{array}{c}0.0247^{* *} \\
(1.98)\end{array}$ & $\begin{array}{c}0.0250^{* *} \\
(2.00)\end{array}$ & $\begin{array}{c}0.0250^{* *} \\
(2.00)\end{array}$ & $\begin{array}{c}-143.9100^{* * *} \\
(-2.82)\end{array}$ & $\begin{array}{c}-142.4625^{* * *} \\
(-2.79)\end{array}$ & $\begin{array}{c}-142.1500^{* * *} \\
(-2.79)\end{array}$ \\
\hline $\mathrm{CSU}$ & $\begin{array}{c}-0.0476 \\
(-1.15)\end{array}$ & $\begin{array}{c}-0.0469 \\
(-1.14)\end{array}$ & $\begin{array}{l}-0.0474 \\
(-1.15)\end{array}$ & $\begin{array}{l}204.9707 \\
\quad(0.62)\end{array}$ & $\begin{array}{l}208.8540 \\
\quad(0.63)\end{array}$ & $\begin{array}{c}209.3233 \\
(0.63)\end{array}$ \\
\hline SPD & $\begin{array}{c}-0.1385^{* *} \\
(-2.07)\end{array}$ & $\begin{array}{c}-0.1370^{* *} \\
(-2.05)\end{array}$ & $\begin{array}{c}-0.1353^{* *} \\
(-2.03)\end{array}$ & $\begin{array}{l}491.4961 \\
\quad(1.00)\end{array}$ & $\begin{array}{c}498.7508 \\
(1.01)\end{array}$ & $\begin{array}{c}498.5980 \\
(1.01)\end{array}$ \\
\hline ACC_MOTOR & $\begin{array}{c}-0.0045^{* *} \\
(-2.37)\end{array}$ & $\begin{array}{c}-0.0045^{* *} \\
(-2.36)\end{array}$ & $\begin{array}{c}-0.0045^{* *} \\
(-2.35)\end{array}$ & $\begin{array}{c}3.1267 \\
(0.45)\end{array}$ & $\begin{array}{c}3.1553 \\
(0.45)\end{array}$ & $\begin{array}{c}3.0204 \\
(0.44)\end{array}$ \\
\hline ACC_CITIES & $\begin{array}{c}-0.0014^{* * *} \\
(-3.01)\end{array}$ & $\begin{array}{c}-0.0014^{* * *} \\
(-3.02)\end{array}$ & $\begin{array}{c}-0.0014^{* * *} \\
(-2.98)\end{array}$ & $\begin{array}{c}-2.8229^{* *} \\
(-2.10)\end{array}$ & $\begin{array}{c}-2.8252^{* *} \\
(-2.08)\end{array}$ & $\begin{array}{c}-2.7786^{* *} \\
(-2.04)\end{array}$ \\
\hline EDUC & $\begin{array}{c}-0.0011 \\
(-1.57)\end{array}$ & $\begin{array}{l}-0.0011 \\
(-1.55)\end{array}$ & $\begin{array}{l}-0.0011 \\
(-1.47)\end{array}$ & $\begin{array}{l}-4.7151 \\
(-1.61)\end{array}$ & $\begin{array}{l}-4.6833 \\
(-1.60)\end{array}$ & $\begin{array}{c}-4.5510 \\
(-1.55)\end{array}$ \\
\hline Constant & $\begin{array}{l}1.3255 \\
(1.03)\end{array}$ & $\begin{array}{c}1.2869 \\
(0.99)\end{array}$ & $\begin{array}{c}1.2662 \\
(0.98)\end{array}$ & $\begin{array}{c}39044.33^{* * *} \\
(7.41)\end{array}$ & $\begin{array}{c}38849.2784^{* * *} \\
(7.38)\end{array}$ & $\begin{array}{c}38773.618^{* * *} \\
(7.36)\end{array}$ \\
\hline \# Obs. & 8,120 & 8,120 & 8,120 & 8,120 & 8,120 & 8,120 \\
\hline$R^{2}$ & 0.431 & 0.431 & 0.430 & 0.402 & 0.401 & 0.401 \\
\hline$F$ & 201.83 & 202.41 & 202.79 & 155.27 & 156.03 & 155.25 \\
\hline
\end{tabular}


Table A.9: Second stage OLS estimates for employees at place of residence and place of work

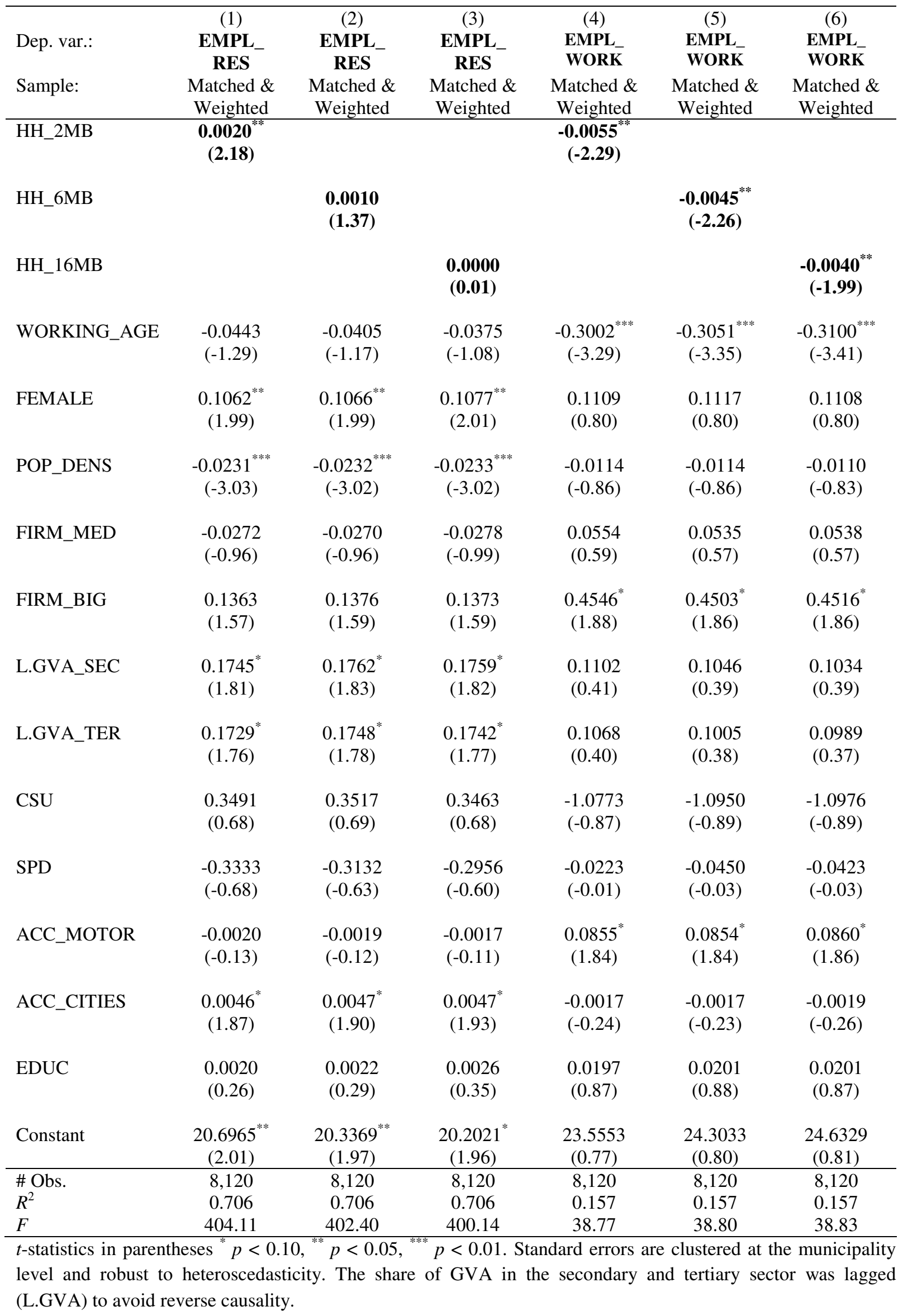




\section{References}

Ahlfeldt, G., P. Koutroumpis and T. Valletti (2015), Speed 2.0 - Evaluating Access to Universal Digital Highways, forthcoming Journal of the European Economic Association.

Akerman, A., I. Gaarder and M. Mogstad (2015), The Skill Complementarity of Broadband Internet, Quarterly Journal of Economics 30, 1781-1824.

Arvin, B. and R. Pradhan (2014), Broadband Penetration and Economic Growth Nexus: Evidence from Cross-country Panel Data, Applied Economics 46, 4360-4369.

Ashenfelter, O. (1978), Estimating the Effect of Training Programs on Earnings, Review of Economics and Statistics 60, 47-57.

Atasoy, H. (2013), The Effects of Broadband Internet Expansion on Labor Market Outcomes, Industrial \& Labor Relations Review 66, 315-345.

Bavarian Ministry of Economic Affairs and Media, Energy and Technology (2012), Schnelles Internet für Bayern - Bilanz des Bayerischen Breitbandförderprogramms 2008 bis 2011, Munich.

Belloc, F., A. Nicita and M. Rossi (2012), Whither Policy Design for Broadband Adoption? Evidence from 30 OECD Countries, Telecommunications Policy 36, 382-398.

Bertschek, I., W. Briglauer, K. Hüschelrath, B. Kauf and T. Niebel (2016), The Economic Impacts of Telecommunications Networks and Broadband Internet: A Survey, ZEW Working Paper, Mannheim.

Bresnahan, T. and M. Trajtenberg (1995), General Purpose Technologies 'Engines of Growth'?, Journal of Econometrics 65, 83-108.

Briglauer, W. (2015), How EU Sector-specific Regulations and Competition Affect Migration from Old to New Communications Infrastructure: Recent Evidence from EU27 Member States, Journal of Regulatory Economics 48, 194-217.

Cameron, A.C. and P. Trivedi (2005), Microeconometrics: Methods \& Applications, Cambridge University Press, Cambridge.

Canzian, G., S. Poy and S. Schüller (2015), Broadband Diffusion and Firm Performance in Rual Areas: Quasi-Experimental Evidence, IZA Discussion Paper No. 9429, Bonn.

Czernich, N. (2014), Does Broadband Internet Reduce the Unemplyoment Rate? Evidence from Germany, Information Economics and Policy 29, 32-45.

Czernich, N., O. Falck, T. Kretschmer and L. Woessmann (2011), Broadband Infrastructure and Economic Growth, Economic Journal 121, 505-532.

De Stefano, T., R. Kneller and J. Timmis (2014), The (Fuzzy) Digital Divide: The Effect of Broadband Internet Use on UK Firm Performance, University of Nottingham Discussion Paper No. 14/06, Nottingham.

European Commission (2014), You Can't Improve What You Can't Measure: State Aid Evaluation, Competition Policy Brief, Issue 7, June 2014, Brussels. 
European Commission (2012), Communication from the Commission to the European Parliament, the Council, the European Economic and Social Committee and the Committee of the Regions, EU State Aid Modernisation (SAM), COM(2012) 209 final, Brussels.

Fabritz, N. (2013), The Impact of Broadband on Economic Activity in Rural Areas: Evidence from German Municipalities, Ifo Working Paper No. 166, Munich.

Forman, C., A. Goldfarb and S. Greenstein (2012), The Internet and Local Wages: A Puzzle, American Economic Review 102, 556-575.

Heckman, J., J. Smith and N. Clements (1997), Making the Most out of Programme Evaluations and Social Experiments: Accounting for Heterogeneity in Programme Impacts, Review of Economic Studies 64, 487-535.

Heckman, J., H. Ichimura, J. Smith and P. Todd (1998), Characterizing Selection Bias Using Experimental Data, Econometrica 66, 1017-1098.

Ivus, O. and M. Boland (2016), The Employment and Wage Impact of Broadband Deployment in Canada, forthcoming Canadian Journal of Economics.

Kandilov, I. and M. Renkow (2010), Infrastructure Investment and Rural Economic Development: An Evaluation of USDA's Broadband Loan Program, Growth and Change 41, 165-191.

Kolko, J. (2012), Broadband and Local Growth, Journal of Urban Economics 71, 100-113.

Lechner, M. (2001), Identification and Estimation of Causal Effects of Multiple Treatments under the Conditional Independence Assumption, in: Lechner, M. and F. Pfeiffer (eds.), Econometric Evaluation of Labour Market Policies, Physica Publishing, Heidelberg, 1-8.

Montolio, D. and F. Trillas (2013), Regulatory Federalism and Industrial Policy in Broadband Telecommunications, Information Economics and Policy 25, 18-31.

Paleologos, J. and M. Polemis (2013), What Drives Investment in the Telecommunications Sector? Some Lessons from the OECD Countries, Economic Modelling 31, 49-57.

Röller, L.-H. and L. Waverman (2001), Telecommunications Infrastructure and Economic Development: A Simultaneous Approach, American Economic Review 91, 909-923.

Sianesi, B. (2004), An Evaluation of the Swedish System of Active Labour Market Programmes in the 1990s, Review of Economics and Statistics 86, 133-155.

Stock, J. and M. Yogo (2005), Testing for Weak Instruments in Linear IV Regression, in: Identification and Inference for Econometric Models: Essays in Honor of Thomas Rothenberg, Chapter 5, 80-108. 